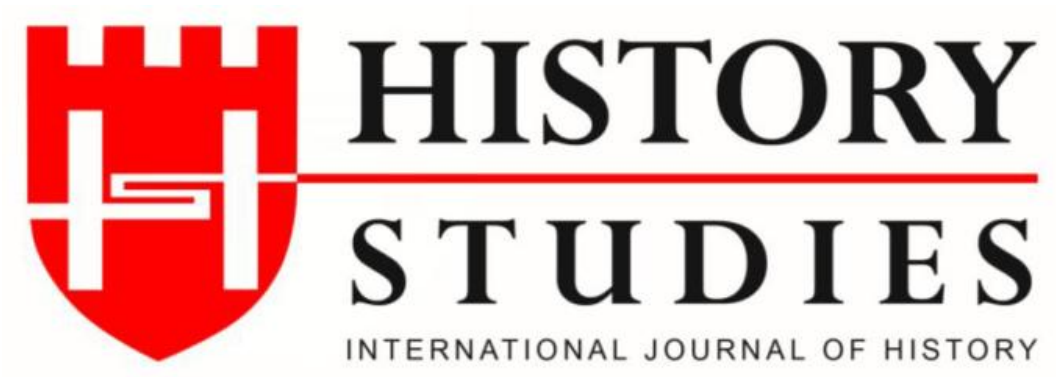

\author{
ISSN: 13094173 (Online) 1309 - 4688 (Print) \\ Volume 12 Issue 6, December 2020 \\ DOI Number: 10.9737/hist.2020.965 \\ Araştırma Makalesi
}

Makalenin Geliș Tarihi: 23.07.2020 Kabul Tarihi: 05.10.2020

Atıf Künyesi: Esra Özsüer, "Siyasetin İzdüşümünde Son Dönem Yunan Tarihçiliği ve Temel

Meseleleri", History Studies, 12/6, Aralık 2020, s. 3269-3292.

\title{
Siyasetin İdüşümünde Son Dönem Yunan Tarihçiliği ve Temel Meseleleri
}

The Late Term Greek Historicism in the Projection of Politics and Its Main Issues

\author{
Doç. Dr. Esra Özsüer \\ ORCID No: 0000-0001-6299-5929 \\ İstanbul Üniversitesi
}

$\ddot{O} \mathbf{z}$

XIX. yüzyıldan itibaren sosyal bilimlerde ayrı bir bilim olarak kabul edilen tarih, Ranke'nin de ifade ettiği üzere gerek sanat gerekse bilim öğelerini içermesi sebebiyle siyasetten ayrı düşünülemez. Zira geçmişin bilgisi olmaksızın bugünün anlaşılması imkansızdır. Bu nedenle tarih ve siyaset birbirlerine yakın ve hatta bağımlı iki bilim olarak kabul edilmektedir. Geçmiş bilgisini kullanarak siyasete şekil veren tarih aynı zamanda siyasetin etkisi altında da yeniden inşa edilir. Siyasi iktidarların hakim konumdaki tarih yorumları dönem dönem tarihin farklı okumalar yapmasına ya da iktidarın tekelinde yeniden yorumlanmasına olanak sağlamıştır. Özellikle ulus devlet inşa sürecinde her devlet ulusal bir kimlik ve bilinç yaratma amacıyla tarih ile arasındaki bağını kuvvetlendirmiş, tarih bilimine ve tarihyazımına doğrudan müdahil olmuştur. Bu noktada tarihin siyaseti şekillendirdiği gibi siyaset de bir süre sonra tarihi biçimlendirmiştir. Sonuç olarak ulus-devletler kendi ideolojilerine göre şekillenen resmi tarih anlayışını eğitim yoluyla tüm vatandaşlarına ve onların düşünce yapılarına entegre etmeye başlamıştır.

Bu makalede de Yunanistan'da son yirmi yılda değişen siyasi süreçlerin Yunan tarihçiliği üzerindeki etkileri ve tarihyazımını nasıl şekillendirdiği incelenmeye çalışılmıştır. Makalede Yunan siyasetinin Yunan tarihyazımı ile paralel seyirde ilerlediği Yunan kaynakları ve yayınları üzerinden örneklendirilmiştir.

Anahtar Kelimeler: Yunanistan, Modern Yunan Tarihi, Türk-Yunan İlişkileri, Tarihyazımı, Siyaset

\begin{abstract}
The history, which has been accepted as a separate science in the social sciences since the 19th century, cannot be considered apart from politics, as Ranke has stated that it contains both art and science elements. Because without the knowledge of the past, it is impossible to understand today. For this reason, history and politics are accepted as two close and even dependent sciences. History, which shapes politics by using past knowledge, is also rebuilt under the influence of politics. The dominant historical interpretations of political governments have allowed the history to take different readings from time to time, or to be reinterpreted in the monopoly of power. Especially in the nation-state building process, each state strengthened its ties with history in order to create a
\end{abstract}


national identity and consciousness, and was directly involved in the science of history and historiography. At this point, as history has shaped politics, politics has shaped history after a while. As a result, nation-states have begun to integrate the official understanding of history, shaped according to their ideology, to all its citizens and their structures of thought through education.

In this article, it has been tried to examine the effects of political processes that have changed in Greece in the last twenty years on Greek historiography and how they have shaped historiography. The article is exemplified by the Greek sources and publications in which Greek politics progressed in parallel with Greek historiography.

Keywords: Greece, Modern Greek History, Greek-Turkish Relations, Historiography, Politics

\section{Giriş}

Antik dönemde olgusal niteliğin sınırları dışında varlık alanı oluşturan ve mitoloji ile anlamdaş kullanılan tarih, (Lat. historia, İt. storia, Fr. historie, İng. history, Alm. historie, Yun. istoria) İyon lehçesinde "bildirme", "haber alma yoluyla bilgi edinme"; Attika lehçesinde de "görerek, tanık olarak bilme" manasında kullanılmıştır. Ancak tarih (istoria) teriminin açıklama olanağı bulunamayan doğaüstü olaylar hakkında tanıklık bilgisi de göz önüne alındığında genel açıklamaya dâhil edilemeyen fakat "gözlenen" ve "tanık olunan" olayların bilgisi anlamı da bulunmaktadır. İstoria terimini ilk defa insani-toplumsal olaylar hakkında kullan Herodot, yazığ 1 | istorias apodeiksis adlı eserinde bu sözcüğü insanların ve insan topluluklarının başından geçenleri kaydetme yoluyla edindiği bilgi olarak tanımlamıştır. Bu noktada Antikçağdan beri mitoloji ile özdeşleşen tarih, gerçekte bizzat yaşanmış ve şahitlik edilmiş vakalar üzerinden değerlendirilmeye başlanmıştır. Daha sonra Thukydides, terimin sadece bir aktarma-kaydetme işi olmadığını aynı zamanda geçmişte yaşanan insani-toplumsal olayların değerlendirilmesi ve yorumlanmas1 etkinliği olduğunu da belirtmiştir. ${ }^{1}$

Aristoteles, istoria'ya tarihyazıcılığı (historiyografi) adını vermiş ve onu bir edebiyat türü olarak şiir sanatının altına koymuştur. ${ }^{2}$ Heredot ve Thukydides ile birlikte XIX. yüzyıla kadar istoria sözcüğü bireysel ve rastlantısal olayların aktarımı şeklinde çift anlam üzerinden yorumlanmış ve edebiyatın bir alt dalı görülmüştür. Fakat XIX. yüzyılda edebiyata bağlı bir dal olmaktan çıkan tarih (istoria), bilim olma yolunda ilerleme kaydetmiş, bununla birlikte devlet ve toplumun derinlemesine anlaş1lıp değerlendirilmesi için geçmişi, neyse o şekilde (wie es eigentlich gewesen) göstermeye çalışmıştır. ${ }^{3}$ XIX. yüzyılda tarihteki bu yön değişikliğine öncülük eden Ranke, Klasik Historisizm ile adlandırılan anlayışa göre tarihi büyük adamların ön plana çıktığı diplomasi tarihi olarak tanımlamıştır. ${ }^{4}$ Lakin 1961 yılında tarih mesleğinden olmayan eski diplomat-gazeteci Edward Hallet Carr, İngiltere'de, Tarih Nedir? başlıklı ince bir kitap yayımlamış ve tarih konusunda bilinen tüm ezberleri yeniden düşündürmüştür. 1929'dan itibaren Fransa'da çıkan Annales d'Historie Economique et Sociale'in başında bulunan Lucién Febvre ve Marc Bloch ile birlikte Carr, XX. yüzyıl tarih yazıcıllğına yepyeni bir soluk getirmiş̧tir. Lucién Febvre ve Marc Bloch önderliğinde ortaya çıkan ve Braudel ile zirveye tırmanan bu akım (Annalés Ekolü) tarihsel bir konuyu çok daha derinlemesine analiz ederek onun aynı zamanda coğrafi, ekonomik, sosyal ve siyasal yönlerini de ele almıştır.

Bu makalede de Annalés Ekolü üzerinden bir yol takip edilmiş ve Yunanistan'da tarihçiliğin gündemini anlayabilmek için bilhassa dönem ve koşulların incelenmesi yazar tarafından zaruri görülmüştür. Dolayısıyla söz konusu çalışmada Uluslararası İlişkiler alanının ilk disiplini kabul

${ }^{1}$ Doğan Özlem, Tarih Felsefesi, Notos Kitap, İstanbul 2012, s. 25-26.

2 Özlem, a.g.e., s. 27.

${ }^{3}$ Edward H. Carr, Tarih Nedir?, İletişim yay., İstanbul 2013, s. 59.

${ }^{4}$ Nazım Beratlı, "Bilim mi - Sanat mı - Propaganda mı? Tarih Nedir?”, Kıbrıs Yazıları, Sayı 3, Yaz-Güz 2006, s. 4. 
edilen Siyasi Tarih tespitlerinin gerekliliği göz ardı edilememiştir. Zira yazar, siyasi süreçlerin oluşturduğu bütün vakaları ve bu süreçlere katılan aktörleri disiplinlerarası bir çalışmanın vurgulanması açısından önemli saymış ve modern tarihyazımında da incelenmesi gerekli bir

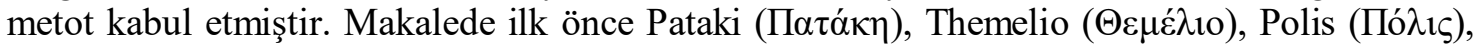

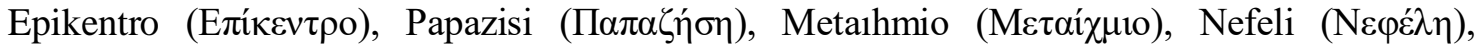
Aleksandreia (A $\lambda \varepsilon \xi \alpha ́ \alpha \delta \rho \varepsilon ı \alpha)$ gibi Yunanistan'ın önde gelen büyük yayınevlerinin 2000 yılından günümüze kadar çıkardığı kitaplar incelenmiştir. Söz konusu kitaplar arasından bilhassa Yunan tarihçiliğinde ses getirenler siyasi konjonktüre bağlı bir şekilde, dönemin anlaşılmasına olanak sağlayacak örneklerle açıklanmıştır. Yine Yunanistan'ın dijital ortamda da en geniş dağıtım ağına sahip olan kitapçıları İanos (I $\alpha v o ́ \varsigma)$, Politeia (Пo $\lambda \imath \tau \varepsilon i ́ \alpha)$ ve Public'deki son yirmi yılın "en çok satan" tarih kitapları araştırılmış ve makalede siyasi dönemlere göre kategorilendirilmiştir. Makalede incelenen bir diğer alan ise Yunanistan'da çıkan akademik ve popüler tarih

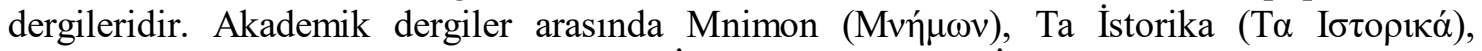

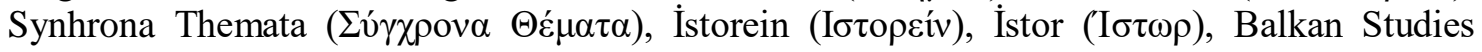

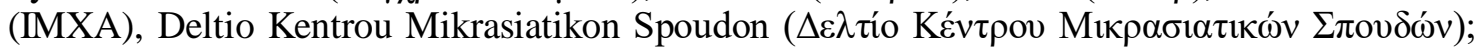

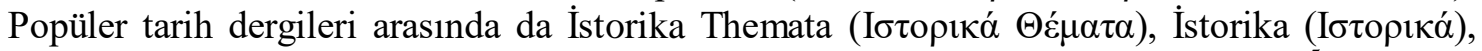
Ardin ('A $\delta \delta \eta v)$ bulunmaktadır. Akademik tezler, Ulusal Dokümasyon Merkezi (EKT) ${ }^{5}$ ve Yunan Ulusal Tez Arşivi ${ }^{6}$ veri tabanından araştırılarak incelenmiştir.

\section{Modern Dönemde Yunan Tarihçiliği ve Değişim Evreleri}

XIX. yüzyılda Yunan tarihyazımı, Antik Yunan (Klasik Dönem) ile Çağdaş Yunan'1 Helenizm adı verilen zincirin ayrilmaz halkaları kabul eden resmi bir ideoloji üzerinden şekillenmiştir. ${ }^{7}$ Temelde bu ideoloji tıpkı Avrupa'da da kendisine etkinlik alanı yaratan milliyetçiliğin diğer varyantları gibi tarihsel unsurlardan dayanak sağlamıştır. Örneğin XIX. yüzyılda Avrupa tarihyazımında ortaya çıkan ulusal karakter mitosuna göre her ulusun kendine özgü mizacı vardır. Ulusların kusurları olduğu kadar meziyetleri de bulunmaktadır. Ancak bu dönemin en belirgin özelliği ulusların kendi tarihlerindeki eksikliklerden ziyade erdemlerini ön plana çıkarma eğilimidir. ${ }^{8}$ Ulusal karakteroloji olarak tanımlanan bu anlayışa göre Yunanlar da devletin kuruluş tarihi olan 1830 yılının ilk on senesinde Yunan tarihini Çağdaş Yunanlar ile Antik Yunanlar arasındaki kopmaz bağ teorisi (süreklilik) üzerinden şekillendirmiştir. Öyle ki XIX. yüzyıl Yunan tarihyazımında en dikkat çeken husus Çağdaş Yunanların merkeze koyduğu kendi kimliğini diğer uluslarla devamlı kıyaslama çabasıdır. Aydınlanma ruhunun etkisiyle kaleme alınan tarih kitaplarında Çağdaş Yunanlar bugünkü Avrupa'nın köklerini oluşturan Antik

\footnotetext{
${ }^{5} \mathrm{http}: / /$ www.ekt.gr [Erișim tarihi: 19.07.2020]

${ }^{6} \mathrm{https} / / /$ www.didaktorika.gr/eadd/[Erişim tarihi: 19.07.2020]

${ }^{7}$ Geleneksel olarak Modern Yunan Devletinin kurulmasıyla başlatılan ve XIX. yüzyılın ikinci yarısından itibaren derlenmeye başlayan Modern Yunan tarihçiliği neredeyse tamamen Helenosentrik (eski Yunan medeniyeti temelli) görünümdedir. Modern Yunan tarihçiliği üç ayrı geçmişi; Antik Yunan, Doğu Roma ve Osmanlı Tarihini içine alan üç yüz yıllık Hellenizm fikri etrafında yapılanan ulusal ideoloji metotlarını takip etmiştir. Bilhassa Aydınlanma dönemiyle ilgili tarihsel incelemeler, politik ve kültürel tartışmalar çok erken tarihlerde Yunan söylemine kolektif kimliğin belirleyici unsuru olarak Antik Yunan ile bağlantı kurma fikrini getirmiştir. Modern Yunan tarihçiliğinin kurucu isimleri olan Zambelios ve Paparrigopoulos, Osmanlı dönemini Doğu Roma (Bizans) sonrası dönemin son bölümü ve Ulusal Devrimin (1821) giriş kısmı olarak ele almıştır. 1940'lı yıllara kadar Osmanlı Tarihi, yaşayan geçmiş olarak incelenirken bu dönemle ilgili maziye gömme politikası uygulanmıştır. Bugün dahi Osmanlı dönemi ile ilgili disipline verilen ad "Bizans Sonrası Çalışmalardır." Evangelia Balta, "Yunan Tarihçiliğinde Türkçe Arşiv Materyalleri”, Çeviren: Cemile Erdek, Türkiye Araştırmaları Literatür Dergisi, Cilt: 8, Sayı: 15, 2010, s. 794-795.

${ }^{8}$ Esra Özsüer, "Tarihin Resmi İdeoloji Tarafından Tahrifatına Bir Örnek: Yunanistan, Turkish History Education, Fall 2018, 7(2), s. 479.
} 
Yunanların soydaşlarıdır. ${ }^{9}$ Nitekim bu mütekabiliyeti ilk dile getiren de Filhelenizm etkisindeki Avrupalılar olmuştur. Bilhassa Aydınlanmacıların tesiri altındaki Avrupalılar kendi kimliklerini Antik Yunan mirası üzerinden tanımlayan Yunanlara, medeniyetin ortak rahminde büyüyen bir embriyo gibi, Avrupalı kardeşleri gözüyle bakmıştır. Dolayısıyla XIX. yüzyıl Yunan tarihyazımında vurgulanan temel mesele, Antik Yunan mirası üzerinden kurgulanan Çağdaş Yunan kimliğini modern zamanların "barbarlarından"10 sıyırarak biricikleştirme çabasıdır. Yunanların Osmanlı hakimiyet dönemine (Turkokratia) karşı reddiyesinin ana kaynağı da inşa edilen bu kurgusal ulus kimliğidir. Yunan tarihyazımında "Karanlık Çağ" olarak tanımlanan Osmanlı hakimiyet dönemi (1453-1821) suskunluklar ile geçiştirilmiş, yok sayılmış bir tarih aralığıdır. ${ }^{11}$ XIX. yüzyılın ilk yarısında ete kemiğe bürünen ve Yunan irredantizminin çıkış noktası sayılan Megali İdea ülküsü de Yunan tarih inşasındaki milliyetçi anlayışın ortaya çıkardığı bir sonuçtur.

Tarih, resmi ideolojinin merkezkaç kuvveti olduğu her durumda tarihyazımı da buna bağlı olarak siyasi pratiklerin bir nevi cariyeliğini üstlenmiştir. Nitekim dünyanın neresinde olursa olsun hangi politik görüşe hizmet ederse etsin siyasal güdülenmeden nasiplenmemiş bir tarihyazımı söz konusu değildir. ${ }^{12}$ Jenkins' in yorumuyla "tarih kuramdır, kuram ideolojidir, ideoloji de çıkardır." ${ }^{13}$ Dolayısıyla tarihin iktidar ilişkilerinden doğmuş olması şaşırtıcı bir sonuç yaratmamaktadır. Tarihin öyle ya da böyle siyasi tutumların şekillendirdiği değer yargılarıyla ilgili bir konu olduğu ${ }^{14}$ düşünüldüğünde politik tarafı da bulunmaktadır. Yunan siyasetinde Megali İdea olarak tanımlanan nasyonalist algı da bu kurama dayandırılan ideolojik bir kurgudur ve Yunan tarihyazımında her dönem belirleyici unsur olmuştur. Yunan tarihçiliğinde bu politik kurgunun temel eseri ise 1860-1874 yılları arasında Yunan tarihinin babası atfedilen Konstantinos Paparrigopoulos'un (1815-1891) kaleme aldığı Yunan Ulusunun Tarihi adlı çok ciltli çalışmadır. ${ }^{15}$ Paparrigopoulos'un söz konusu kitabı neredeyse bir asır boyunca Yunan tarihyazımında kuşku götürmez tek gerçek kabul edilmiş ve anayasa hükmündeymiş gibi onay almıştır. Zaten Yunan tarihçinin bizzat kendisi de Yunan milliyetçiliğinin sürdürülmesinde mücadele veren baş aktörlerden biridir. Ancak 1922 y1lında Yunan ordusunun Küçük Asya Bozgunu ile resmi ideolojiden silinen Megali İdea, beraberinde bu ülkü ile kimlikleşen Yunan milliyetçiliğine de kan kaybettirmiştir. Örneğin Yunan ordularının Anadolu'dan çekildiği 1922

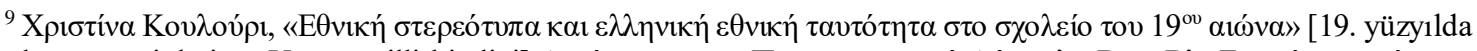

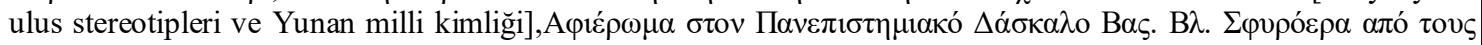

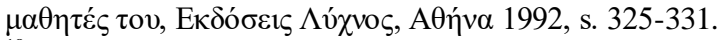

${ }^{10}$ Yunanistan'da XIX. yüzyıl başlarında kültürel ve politik hayata damgasını vuran progonoplixia (atalarla kafayı bozma) ve arkhaiolatria (antik çağ hayranlığı) devletin resmi ideolojisini yansıtan Yunan tarihyazımında oldukça etkilidir. Dolayısıyla Yunanlar ulus kimliğini ne Balkan ne de despot gördüğ̈ Doğu ile tanımlamıştır. Yunanlar için ulus kimliği ırksal ve coğrafi bakımdan Avrupa menşeilidir.

${ }^{11}$ Yunan Tarihini Osmanlı Tarihinden münferit ele almak mümkün değildir. Zira Yunanistan'da üretilen tarih araştırmaları Osmanlı Tarihi ile doğrudan ilişkilidir ve konuyla ilgili Yunanca literatür bir hayli geniştir. Yunanistan'ın önde gelen üniversiteleri, araştırma merkezleri ve vakıfları Osmanlı dönemiyle ilgili kapsamlı çalışmalar yürütmektedir. Örneğin Yunanistan'da Atina Üniversitesi ve Selanik Aristoteles Üniversitesi gibi devlet üniversiteleri Osmanlı araştırmaları alanında saygın bir yer edinmişlerdir. Ayrıca Girit Resmo'da bulunan Akdeniz Araştırmaları Enstitüsü (IMS-FORTH), Yunan Edebiyat ve Tarih Arşivi (ELİA), Küçük Asya Araştırmaları Merkezi (KMS), Aikaterini Laskaridis Vakfı, Benaki-Yunan Kültürü Müzesi, Milli Tarih Müzesi (EIM), Amerikan Klasik Araştırmaları Okulu-Atina (ACSCA), İngiliz Araştırmaları Okulu-Atina (BSA) Ulusal Yunan Araştırmaları Vakfı bünyesinde faaliyet gösteren Tarih Araştırmaları Enstitüsü bilhassa Osmanlı dönemine ilişkin kapsamlı çalışmalar yürütmektedir. İbrahim Alper Arısoy \& Aşkın Özdağoğlu \& Güzin Özdağoğlu \& Muhammet Damar, "Yunanistan'da Osmanlı Tarihi Literatürü Üzerine Bir Değerlendirme" Ankara Anadolu ve Rumeli Araştırmaları, Cilt: 1, Sayı: 1, Yaz 2020, s. 5-16.

${ }^{12}$ Beratl, a.g.m., s. 7.

${ }^{13}$ Keith Jenkins, Tarihi Yeniden Düşünmek, Dost yay., Ankara 1997, s. 43.

${ }^{14}$ Jenkins, a.g.e., s. 134.

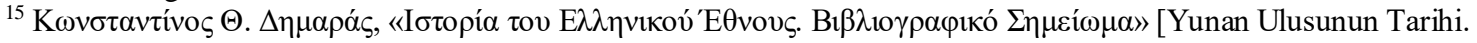

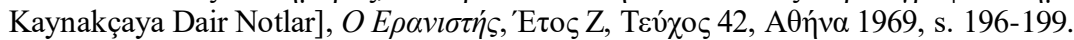


yılı ve sonrası Yunanistan'da siyasi, ekonomik ve sosyolojik bunalımların yaşandığı sancılı bir süreci temsil etmektedir. Küçük Asya Bozgunu ile dağılan Yunan ordusunun bu ağır askeri yenilgisi tüm Yunanistan'da şok etkisi yaratmış ve sorumlulara karşı genel bir protestoya neden olmuştur. Yunan ordularının 5/42 Evzon Alayı kumandanı Albay Nikolaos Plastiras ve Stilyanos Gonatas önderliğinde 11 Eylül 1922 tarihinde gerçekleştirilen askeri darbe sonunda Yunan cephesinde yaşanan trajedinin müsebbibi görülen Kral Konstantin tahtından çekilmek zorunda kalmış ve eski kral yanlısı (anti-Venizelist) hükümet istifa ederek meclis dağıtılmıştır. Üstelik Yunan ordusunun askeri mağlubiyetinin saikası görülen ve aralarında hem siyasi hem askeri kanattan olan altı kişinin ulusal felakete neden oldukları gerekçesiyle kurşuna dizilmesi (Altılar Davas1) Yunan siyasi arenasındaki politik kaosun daha fazla tırmanmasına sebebiyet vermiştir. Sonrasında Doğu Trakya'nın Yunan kuvvetlerince boşaltılması ve Lozan Barış Antlaşmasının imzalanması Yunan tarihyazımında Megali İdea ülküsüne dayanan enosis taleplerini de bir süre gündem dışı bırakmıştır. Yunan kolektif belleğinde "kurtarılmayı bekleyen topraklar" ve "kurtarılmayı bekleyen kardeşler" ülküsüyle idealize edilen Megali İdea, artık "kayıp vatan" kabul edilen Anadolu topraklarında, 9 Eylül 1922'de tamamen sulara gömülmüş eski bir ülküdür. Oysa Yunan tarihyazımındaki temel milliyetçi öğe sayılan şecerecilik (Antik Yunan, Doğu Roma, Çağdaş Yunan) ideolojik iflasın aksine varlığını eskiye nazaran çok daha fazla güçlendirmiş̧tir.

XX. yüzyıl Yunanistan'ında yaşanan içtimai değişimler ve gelişimler, bilhassa tarihçilerin ilgisini ekseriyetle toplumsal konulara çevirmiştir. Yunanistan Komünist Partisi'nin (KKE) 1918 yılında kurulmasıyla birlikte tarihyazımında da eş zamanlı biçimde Marksist tarihçilik gündeme taşınmıştır. Fakat bu yeni yaklaşım uzun soluklu bir etki yaratmamış ve hatta akademik tarihçiliğin içine bile sızamamıştır. Özellikle iki savaş arası dönemde gelenekçi kanadı temsil eden üniversite hocaları Marksist tarihçilik hususunda oldukça katı ve önyargılı bir tutum sergilemiştir. Öyle ki bazı doktora öğrencilerinin sol eğilimleri nedeniyle doktora unvanları reddedilmiştir. ${ }^{16}$ Öte yandan Yunan tarihçiliğinde farklı görüş ve seslerin daha çok çıktığı bir dönemin de kapıları aralanmıştır. Artık milliyetçiler ve resmi tarih sözcüleri dışında Yunan tarihyazımında sosyalistler ve Marksistler de varlık alanı oluşturmaya çalışmıştır. Tarihyazımına yeni pencereler açmaları bakımından bu ezber bozan tarihçilerin ifade ettikleri oldukça kayda değerdir. Örneğin 1821 Mora İsyanı bu döneme kadar Hristiyan Ortodoks inancı ile ulusal bilinç etrafında bir araya gelmiş “tutsak" bir milletin Osmanlı Devleti'ne karş1 yürüttüğü özgürlük hareketi şeklinde sunulmuştur. Yani Yunan tarihyazımında 1821 Ayaklanması, esareti yıkmak için "tirana" karşı verilmiş bir ulus mücadelesidir. Oysa XX. yüzyıl Yunan tarihçiliğinde 1821 Mora İsyanının toplumsal ve ekonomik yönleri de irdelenmeye başlamıştır. İsyan, sadece tüm Yunan ulusunun dahil olduğu bir bağımsızlık mücadelesi şeklinde ezber cümleler ile ifade edilmemiş aynı zamanda bazı grupların isyan süreci boyunca kişisel menfaatleri de tartışmaya açılmıştır. Mesela Filhelenizm etkisi dışında isyanın başarıya ulaşmasını istemeyen, kıdemli din görevlileri, Kocabaşlar ve Fenerliler gibi Osmanlı Devleti ile dengeli siyaset izlenmesini savunan bir kesimin varlığından ilk kez bu dönemde bahsedilmiştir. Yannis Kordatos'un 1924 yılında neşrettiği 1821 Yunan Devriminin Toplumsal Önemi ${ }^{17}$ adlı kitabı bu alanda kaleme alınmış kayda değer bir eserdir. Kitapta 1821 isyanı, sadece etnik nedenlerden ötürü vuku bulmuş tarihsel bir olay gibi gösterilmemiş aynı zamanda sürecin toplumsal ve ekonomik yönlerine de 1şık tutulmuştur. Ancak kitapta ifade edilen yeni ulus tezleri Yunan tarih inşasının kiremitlerini sarsan

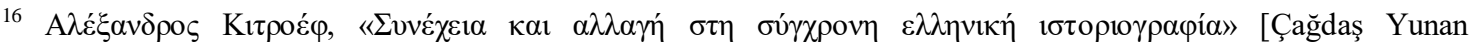

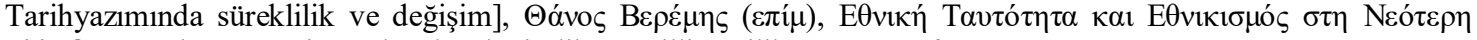

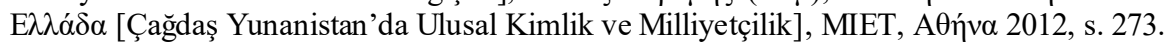

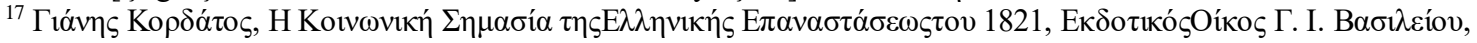
A $\theta$ ท́va 1924.
} 
etki yarattığından dönemin hükümeti ve Kutsal Sinod tarafindan bir nevi aforoz edilmiştir. Kordatos'a göre Yunan gençlerini zehirlediği iddiasıyla devlet tarafindan okunmaması tavsiye edilen söz konusu kitap, aslında Modern Yunan Tarihinin en önemli konularından birini tarihsel materyalizm yöntemiyle incelediği için yasaklanmıştır. ${ }^{18}$ Dolayısıyla XX. yüzyıl Yunan tarihçiliğindeki bu türden farklı okumalar ilk başlarda sancılı ve bir o kadar da kolay kabul edilmemiştir.

İki savaş arası dönem Yunanistan'da entelektüel sınıf açısından muhafazakârlığın ve antikomünizmin hüküm sürdüğ̈ yadsılı bir dönemdir. 1936-1941 yılları arasında Yunan siyasi tarihinde "Metaksismos" olarak da bilinen Metaksas diktatörlüğü, sansür, polis devleti, parlamentarizm karşıtlığı, III. Dönem Yunan Medeniyeti hedefiyle yoğrulmuş ve Ari kültür öğeleriyle donatılmış Yunan milliyetçiliği, militarizm ve İoannis Metaksas tarafından kurulan faşist yapılanma EON (Ulusal Gençlik Örgütü) güdümünde işleyen siyasal bir düzeni temsil etmiştir. ${ }^{19}$ 1941-1944 y1lları arasında Yunanistan'daki İtalyan, Alman ve Bulgar İşgali; 19461949 yılları arasında Yunanistan'ı iki zıt kutba ayıran Yunan İç Savaşı, ülkeyi siyasi ve toplumsal polarizasyona sürükleyen diğer önemli süreçlerdir. ${ }^{20}$ Savaş döneminde Yunan tarihçiliği de bu olumsuz koşullar altında düşünce özgürlüğ̈̈nün olmadığı, her tür yayının katı sansürden geçirildiği bir dönemde var olma çabasından öteye gidememiştir. Yunan İç Savaşı sonrasında Yunanistan (1950), Parlamenter Demokrasi ile yönetilmesine rağmen, 1947'den 1991 yılına kadar tüm dünyada derin hissedilen ve uluslararası arenada da siyasi ve askeri gerginlik olarak tabir edilen Soğuk Savaş yıllarının etkisiyle Cunta döneminden farklı bir yol takip edememiştir. Çünkü Yunan İç Savaşını takip eden 1950'li yıllar, Kızıl Tehlike olarak adlandırılan komünizm korkusu altında, akla düşman, baskıcı bir dönemdir. ${ }^{21} 1950$ 'li yılların Yunanistan'ı sol fikirlerin ve siyasi sol partilerin yasadışı sayıldığı, ifade özgürlüğünün kısıtlandığı bir ortamda tarihyazımını da bu sınırlar içinde belirlemiştir. Birçok bilim insanı gibi yenilikçi Yunan tarihçileri de ülkeyi ele geçiren muhafazakarlık zincirini kırmak ve hakim suskunluğu bozmak amacıyla yurt dışına göçmeye başlamıştır. Yunanistan sınırları içinde yaşayan tarihçilerin büyük bir kısmı da özellikle 1945 sonrasında Batı'daki tarih yazıcılığını değiştiren köklü gelişimleri takip edemediğinden tarihçilikte geleneksel kalıpların dışına çıkamamıştır. Oysa ülke sınırları dışında Yunan Tarihi üzerine eserler veren tarihçiler Batı'daki tüm gelişmeleri özümseyerek özgür bir biçimde eserlerini ortaya çıkarmışlardır. Örneğin Yunanistan ile ilgili çalışmalarını Amerika'da sürdüren Kanada kökenli tarihçi Leften Stavros Stavrianos'un 1958 yılında İngilizce yayımladığı 1453 'e kadar Balkanlar ${ }^{22}$ adlı kitabı bu minvalde değerlendirilebilecek önemli bir eserdir. Stavrianos, söz konusu eserinde, Yunan milliyetçiliğini diğer Balkan milliyetçilikleriyle birlikte siyasi ve ideolojik çerçevede derinlemesine analiz etmiştir. Stavrianos, Amerika'da Yunanistan ile ilgili tarih çalışmaları yapan Speros Vryonis gibi birçok bilim insanına da örnek teşkil etmiş bir isimdir. Amerika kökenli Speros Vryonis'in 1978 yılında kaleme aldığı Ortaçă̆ ve Modern Yunan Kültüründe Geçmiş ${ }^{23}$ adlı çalışması Yunan tarih zincirinde şecerecilik kavramına dair önemli bilgiler sunmaktadır. Yine 1940 yılında siyasi gerekçelerle Fransa'ya iltica eden tarihçi Nikolas Svoronos'un çalışmaları sayesinde neo-Marksist gelenek Yunan

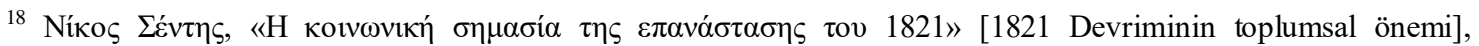
https://marxismos.com/koinwniki-simasia-epanastasi-1821/ [Erişim tarihi: 18.05.2020]

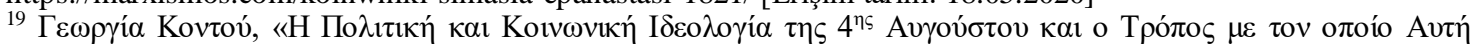

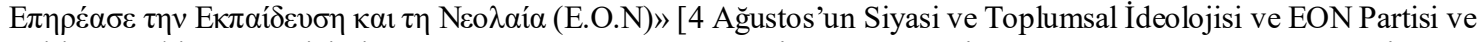

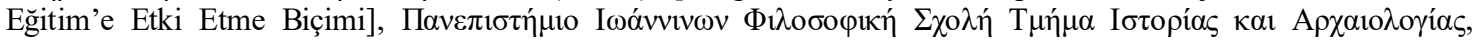

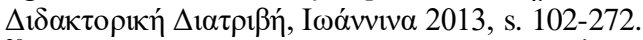

${ }^{20}$ Richard Clogg, Modern Yunanistan Tarihi, İletişim yay., İstanbul 1997, s. 125-177.

${ }^{21}$ Kıтров́ $\varphi$, a.g.m., s. 273.

${ }^{22}$ Leften Stavros Stavrianos, The Balkans since 1453, New York University Press, New York 2000.

${ }^{23}$ Speros Vryonis, The Past in Medieval and Modern Greek Culture, Undena Publications, New York 1978.
} 
tarihçiliğinde kendisine bir yer edinebilmiştir. Svoronos'un 1953 senesinde Paris’te Fransızca yayımladığı Çă̆daş Yunan Tarihi ${ }^{24}$ adlı eseri Marksist yönelimle Yunan tarihini ele alan ilk kitaptır.

1967-1974 yıllanı arasında Yunanistan'da ikinci kez yaşanan Askeri Cunta ${ }^{25}$, önceki dönemin tüm olumsuz şartlarını çok daha fazla ağırlaştırarak Yunan tarihçiliğindeki sınırları bir kez daha keskinleştirmiştir. Kısaca 1950-1974 yılları arasında Yunanistan'daki tarihçilerin büyük bir kısmı geleneksel çizgiyi aşmadan eserlerini üretmiş ve bilhassa ideolojik duyarlılığa sadık kalmıştır. Bu dönemde yazılan kitapların konusu genellikle 1821 Mora İsyanı (1821-1828), Makedonya Tarihi ve Yunan tarih zincirinin önemli ve vazgeçilmez halkası görülen Doğu Roma Tarihi ile yakından ilintilidir. Dönemin bir başka ilgi çekici noktası ise Yunan tarihçiliğinde ortaya çıkan çift başlılık olmuştur. Yunan tarihçiliğinde gelenekçiler ve modernistler şeklinde iki farklı görüş ortaya çıkmıştır. İlk görüşün üyelerini Yunanistan'da yaşayan ve dolayısıyla tarih yazıcıllğında savaş öncesi geleneksel çizgiyi mecburen devam ettiren tarihçiler oluştururken, ikinci görüşün üyeleri ise yurtdışında ikamet eden ve İkinci Dünya Savaşı sonrasında Avrupa'daki modern tarih yazıcılığını bizzat takip eden Yunan tarihçileridir. Dolayısıyla tarihyazımında ortaya çıkan bu çatallı tutum tarihçilerin eserlerine de yansıyan bir sonuç ortaya çıkartmıştır. 1974 yılında Yunanistan'da Askeri Cunta sona erip parlamenter demokrasi kurulduğunda $^{26}$, Tarih bilimi ve Tarih yazıcılığı da nihayet beklediği özgürlük alanına kavuşabilmiştir. Yunan tarihçiler artık herhangi bir politik engellemeye maruz bırakılmadan eserlerini özgürce vermeye başlamış ${ }^{27}$ bilhassa demokrasi ve hukukun yeniden tesisi, tüm siyasal partilerin yasallaştırılması ile birlikte yurtdışında yaşamayı tercih etmiş ya da buna zorunlu kalmış pek çok tarihçinin de Yunanistan'a dönmesine olanak sağlamıştır. Yurtdışından dönen tarihçiler akademik görevler üstlenerek üniversite kürsülerinde görev almaya başlamış, bir kısmı da eski ve yeni kurulan araştırma merkezlerini tekrardan canlandırmıştır. Yunan kolektif belleğinde, Askeri Cunta ve Kıbrıs meselesi, iç savaş sonrasında ülkede kurulan politik düzenin iflas etmesinde iki önemli neden olarak kabul edilmiştir. Bu dönemde Komünist Partinin (KKE) legalleşmesi, Kıbrıs meselesi, diktatörlük dönemi gibi konular Yunan tarihçiliğinde de ilgi çeken meselelerin başında gelmektedir. Özellikle Yunan tarihyazımında Marksist teoriler adeta çağın modası gibi ziyadesiyle ilgi görmüştür. ${ }^{28}$

Netice itibariyle Yunanistan'da demokrasinin kurulduğu 1974 yılından 2000'li yıllara kadar geçen sürede Yunan tarihçiliğinin öncelikli gündemi geçmiş dönemlerde uzun süre yasaklanmış konularla ilgilidir. Bu konuların başında Marksist görüşlere yer veren tarihi olaylar ve Marksist teoriler üzerinden yorumlanan tarih araştırmaları bulunmaktadır. 1990'lar ve sonrasında Yunan tarihçiliği nihayet belli bir dengeyi yakalayabilmiştir. Siyasi Tarih araştırmacılarının ilgisini

\footnotetext{
${ }^{24}$ Nicolas G. Svoronos, Histoire de la Grèce moderne, Presses universitaires de France, Paris 1953.

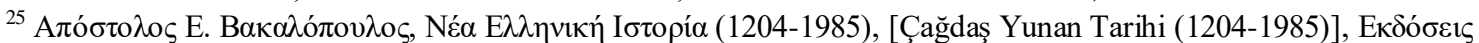

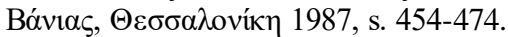

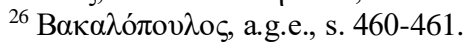

${ }^{27}$ Belirtmekte fayda var ki "özgürce" ifadesi, sınırsız bir özgürlüğün temsili değildir. Zira günümüzde dahi Yunan tarihçiliğinde belli ulusal stereotipleri yıkmak ve ezberi bozacak yeni bilgiler ortaya koymak kolay kabul edilebilen bir adım değildir. Akademik tarihçilik ile popüler tarihçilik arasında belli bir uyumun/dengenin sağlanması, birkaç istisna dışında hala tercih edilendir. Bu istisnalar arasında en dikkat çekeni Tasos Kostopoulos tarafindan kaleme alınan Savaş ve Etnik temizlik. On Yıllık Ulusal Bir Faaliyetin Unutulmuş Yönü, 1912-1922 adlı çalışmadır. Kostopoulos, söz konusu çalışmasında, Yunan resmi tarih tezinin dışında bir yol takip ederek Yunan Makedonya'sında Slav ve Müslüman nüfusa karşı etnik temizlik yapıldığını ifade etmektedir. Kitapta vurgulanan bir diğer önemli konu da Yunan ordusunun Anadolu işgali sırasında Türklere yaptı̆̆ı mezalimdir. Kostopoulos'a göre Yunanistan'ın

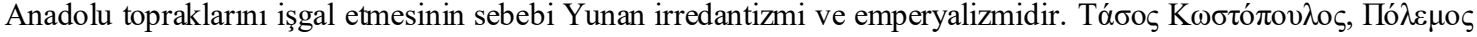

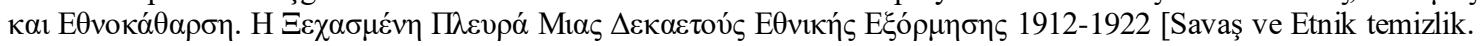
On Y1llık Ulusal Bir Faaliyetin Unutulmuş Yönü, 1912-1922], Bı $\beta \lambda$ ıó $\alpha \mu \alpha$, A $\theta \dot{v} v \alpha 2007$.

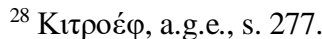


çeken dört temel dönem Yunan tarihçiliğinin de öncelikli gündemini oluşturmuştur. Örneğin Yunan tarihçiliğinde ele alınan ilk dönem, ulusal mücadele olarak kabul edilen 1821 Mora İsyanıdır. Osmanlı Devleti'ne karşı başlatılan 1821 İsyanı, 1830'da Kapodistrias Hükümetinin bağımsız Yunan Devleti'ni kurmasıyla sona ermiştir. ${ }^{29}$ Bu konuda Yunan tarihçi Paparrigopoulos ekolünü takip eden Apostolos Vakalopoulos'un sekiz ciltlik Çağdaş Helenizm Tarihi ${ }^{30}$ adlı eseri Mora İsyanı ile ilgili oldukça kapsamlı çalışmalardan birisi olmuştur. İkinci dönem, Yunan Tarihinde hezeyanla sonuçlanan 1897 Türk-Yunan Savaşı ve bu hezimet sonrasında ülkede aşamalı bir çöküşe giden siyasetin neden olduğu 1909 Gudi darbesini ve Eleftherios Venizelos'un Yunanistan başbakanı olmasıyla başlayan modernleşme sürecini içermektedir. Üçüncü dönem, 1915 yılında başlayan ve Ulusal Bölünme adıyla tanımlanan Yunanistan'daki Venizelist ve anti-Venizelist (Kralcılar) kutuplaşmasıdır. Üçüncü dönemde tarihçilerin yoğunlukla ilgi gösterdiği bir diğer önemli konu da 1919-1922 yılları arasında Yunanların başarısızlıkla sonuçlandırdığı Anadolu işgal yılları olmuştur. Dördüncü dönemde ise 1940-1950 yılları arasında cereyan eden tüm siyasi hadiselerle yakından ilgilenilmiş, İkinci Dünya Savaşı, Alman İşgali, Mihver Devletlerin Yunanistan'ı işgal etmesi, İşgale karşı Yunan halk direnişi, Yunanistan'ın işgalden kurtuluşu, Yunan İç Savaşı ve sağ-sol kutuplaşması, Yunan İç Savaşında Britanya ve Amerika'nın direkt müdahalesi gibi başlıklar Yunan tarihyazımının belirleyici mevzularını oluşturmuştur. Bu temel konuların dışında Yunanistan'da en fazla araştırma yapılan ve üzerinde ciltlerce kitap yazılan başka bir önemli mevzu da 1974 yılında Türkler tarafindan gerçekleştirilen ve Yunan siyasetinde "işgal” ( $\varepsilon 1 \sigma \beta o \lambda \eta ́)$ olarak tanımlanan Kıbrıs Barış Harekatıdır. Türkiye ve Yunanistan arasında 1974 ve sonrasında yaşanan tüm siyasi gelişmeler, makalenin de ana temasını oluşturan 2000 yılı ve sonrasında, Yunan tarihçiliğinin her zaman esas meselelerinden biri kabul edilmiştir.

\section{2000 Yılı Sonrası Yunan Tarihçiliğinin Temel Meseleleri}

Halil Berktay'a göre tarih ile siyasetin ayrılmaz birlikteliği XIX. yüzyıl İngiltere'si ve Victoria dönemine özgü bir yanılsama biçimidir. Zira XX. yüzyıl demokratikleşme sürecinde tarih ve siyaset giderek birbirinden ayrışmışır. ${ }^{31}$ Öte yandan kat'î surette objektif tarih yazılamayacağının altını çizen Halil İnalcık ise tarihin belli politikaları ve ideolojileri yönlendiren, temsil eden bir görüş ve anlayışla ele alındığını ifade etmiştir. ${ }^{32}$ Ranke de tarih ve siyasetin bilimsel manada birbirlerine bağımlı olduğu görüşündedir. Çünkü her siyasi iktidar kendi meşruiyetini korumak için tarihsel bilgiye ihtiyaç duyar. ${ }^{33} \mathrm{Bu}$ noktada tarihin "siyasal bir savaş meydanı" olduğuna değinen Tosh'u da yeniden hatırlamak ve günümüzde de iktidarın tarih yorumunun kitaplara, yazılı ve görsel basına dolayısıyla her yere nüfuz ettiğini ${ }^{34}$ yinelemek hatalı bir çıkarım olmayacaktır. 2000'li yılların Yunanistan'ı bu minvalde değerlendirildiğinde birbirinden kopuk bir tarih-siyaset ilişkisine sahip değildir. Öncelikle 2000 yılından yaklaşık bir on sene öncesinde dünya, uluslararası platformda kabuk değiştirmiş ve haritalar ulusların kendi nüfus kağıtlarıyla birlikte yeni sınırlarını çizmiştir. Söz konusu yapılanma yeni fakat bu yapılanmanın faktörleri eskidir. Aslında dünyada tesis edilmek istenen düzenin kökleri Büyük

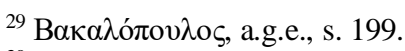

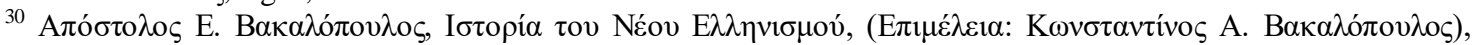

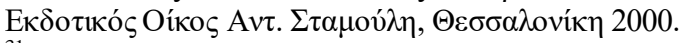

${ }^{31}$ Halil Berktay, "Tarih ve Siyaset", http://serbestiyet.com/yazarlar/halil-berktay/tarih-ve-siyaset-849090 Erişim tarihi: 15.01.2020.

${ }^{32}$ Halil İnalcık, “Tarih ve Politika”,Prof. Dr. Halil İnalcık'ın 29 Mart 2006 tarihinde Ankara Üniversitesi Rektörlüğü

100. Yıl Salonu'nda sunduğu Tarih ve Politika konulu konferans metni, s. 7.

${ }^{33}$ Leopold Von Ranke, The Secret of World History: Selected Writings on the Art and Science of History, Edited by Roger Wines, Fordham University Press, New York 1981, s. 105-118.

${ }^{34}$ John Tosh, Tarihin Peşinde, Çeviren: Özden Arıkan, Tarih Vakfi Yurt yay., İstanbul 1997, s. 11.
} 
Savaş'1 hazırlayan ve Blokların çatışması olarak da bilinen 1904-1914 yılları arasındaki gelişmelere kadar götürülebilir. Uluslararası politikaya farklı bir boyut kazandıran İkinci Dünya Savaşı ise Büyük Savaş'1 sona erdiren barış antlaşmalarının yarattığı dengesizliklerin neticesi olduğu kadar, 1933-1939'da yaşanan gerginliklerin de beklenen sonunu oluşturmuştur. Dolayısıyla 1990-1991 yıllarından itibaren dünyanın yeni bir yapılanma içine girmesine neden olan aktörler, 1980 ve 1990 yılları arasında yaşanan gelişimlerde gizlidir. Ortadoğu Bölgesi ile Sovyetler Birliğinin yıkılmasına ve dağılmasına varan Sovyet Rusya gelişmeleri “bugün”ü doğuran faktörler arasından şüphesiz en önemlisidir. ${ }^{35}$

Gorbaçov iktidarı sırasında Sovyetler Birliği'nin siyasal yapısında başlayan çözülmeler, "1989 İhtilalleri" ile 1991 yılı sonunda dağılmıştır. Üstelik sosyalist "uydular" ve "Birlik" içindeki milletler de Moskova etrafında kalıplaşmış görünen siyasi yapının aslında ne kadar "sallantıll" olduğunu görmekte gecikmemiştir. ${ }^{36}$ Nitekim 1989 yılında Sovyet rejiminin Doğu Avrupa'da çökmesi ile birlikte Doğu Bloku (Demir Perde) da sona ermiştir. Diğer sosyalist ülkelerde olduğu gibi Yugoslav Cumhuriyeti'nde de demokratik hareketler 1989 yılında başlamış ve Doğu Bloku ülkelerindeki gelişmelere paralel biçimde 1990 yılından itibaren bu cumhuriyetlerde de bağımsızlık eğilimleri su yüzüne çıkmıştır. 1991 yılında Slovenya ve Hırvatistan'dan sonra Makedonya'nın da bağımsızlı̆ıını ilan etmesi Yunan siyasetinde adeta bir deprem etkisi yaratmıştır. 17 Şubat 1991 tarihinde "Makedonya" ismiyle kurulan eski Yugoslavya toprağı, Yunan tarihyazımında bugüne kadar kangrenleşen bir sorunsalı yeniden baş gündeme taşımıştır. Nitekim 2019 yılında Yunanistan'ın, SYRIZA (Radikal Sol Koalisyon) hükümeti döneminde (2015-2019) Makedonya ile imzaladığı Prespa Anlaşması, gerilimin zirveye çıkmasına ve faturanın kangrenli organı sağlıklı organlardan ayırmak gayesiyle hareket eden eski başbakan Aleksis Çipras'a kesilmesine sebebiyet vermiştir. Bugün SYRIZAA partisinin hükümetten düşmesi hem iç siyasetinde "olduramadıkları" hem de dış siyasetinde "ihanet" kabul edilen Prespa Anlaşması ile açıklanmaktadır. ${ }^{37}$

2000'li yıllarda Yunan tarihçiliğine damgasını vuran belli başlı konuların iç ve dış siyasette vuku bulan köklü dönüşümlerden farklı bir seyirde ilerlemediği aşikardır. İlk olarak Yunan tarihçiliğinin bu dönemde odaklandığı baş gündemi Doğu Blokunun çökmesiyle birlikte değişen yeni sinırlar üzerinedir. Bilhassa Yunan siyasetinde "Makedonya Meselesi" olarak adlandırilan ve iki ülke arasında çözümsüz çatışmalara sebebiyet veren konu tamamen tarihi bir mesele olarak kabul edilmiştir. Modern Yunan tarihçiliğinin önde gelen isimlerinden biri olan Antonis Liakos, Yunanistan'in XX. Yüzyll ${ }^{38}$ adlı kitabında, Makedonya Meselesinin Osmanlı hakimiyet döneminden beri Balkanlarda bir sorun olduğuna değinmektedir. Liakos'a göre Yunanlar, Makedonya isim hakkının başka bir ülke tarafından kullanılmasını her zaman yanlış görmüştür çünkü bu isim Büyük İskender ile bağlantılı biçimde Yunanlara ait tarihi bir miras kabul edilmiştir. Bu nedenle Yunanistan, Prespa Anlaşmasına kadar, ki bu akit ile 2019 yılında Kuzey

\footnotetext{
${ }^{35}$ Fahir Armaoğlu, 20. Yüzyıl Siyasi Tarihi (1914-1995), Timaş yay., İstanbul 2014, s. 757.

${ }^{36}$ Armaoğlu, a.g.e., s. 811.

${ }^{37}$ Nitekim Yunanistan'ın önde gelen gazetelerinden To Vima (Kürsü), “Prespa Anlaşması: Bir yıl oldu ve twitter unutmadı" başlıklı makalesinde SYRIZZA hükümetinin politik hezimetini söz konusu anlaşma metnine bağlı olarak şu ifadelerle desteklemektedir: "Tam bir yıl önce Prespa Anlaşmasını imzalayan Başbakan Aleksis Çipras, Makedonya'nın Yunanlılığı lehine Yunanistan'ın her köşesinde gösteri yapan Yunan halkının büyük çoğunluğunun iradesini göz ardı ederek, "Anlaşma bu yeni dönemin temellerini atıyor" demişti. Birkaç ay sonra, özellikle Avrupa ve yerel seçimlerden sonra, SYRIZZA, Prespa Anlaşmasından dolayı politik başarısızlığa uğradı. Yunan halkı koalisyon ortağı olan ANEL (Bağımsız Yunanlar) başkanı Panos Kammenos'un partisine yüzde 8 oranında oy verip onları da evlerine gönderdi. SYRIZZA ise kuzey Yunanistan topraklarında seçimlerde yerle bir oldu.” To Bท́ $\mu \alpha, ~ « \Sigma v \mu \varphi \omega v i ́ \alpha \tau \omega v$

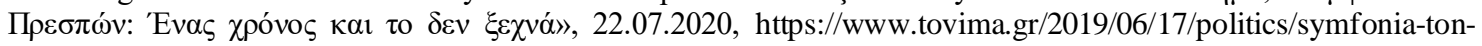
prespon-enas-xronos-kai-to-twitter-den-ksexna/ [Erişim Tarihi: 22.07.2020]

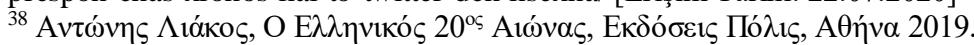


Makedonya resmi adını almıştır, Makedonya ismi yerine Eski Yugoslavya Cumhuriyeti Makedonya (FYROM) tanımını kullanmıştır. Çünkü Yunanlar için ne Makedon ulusu ne de Makedon dili vardır. Yani Makedonya, Yunan kolektif belleğinde Yunan ulus kimliğine ait bir unsurdur ve başka bir devlet tarafindan da bu ismin kullanılması söz konusu bile değildir. Yunanlara göre Makedonya isminin kullanım hakkı Yunanistan'ın Makedonya olarak tanımladığı Selanik, Florina, Kozani, Kesriye (yun. Kastoria), Vodina (yun. Edessa), Serez ve Kılkış'dan oluşan coğrafi alana aittir. Yunanlar Makedonya isminin kullanılmasını kendilerine yönelik irredantist bir hareket olarak algılamıştır. ${ }^{39}$ Dolayısıyla 2000'li yılların başında Yunan tarihçiliğinin gündeminde de Balkan Tarihi, fakat bilhassa Makedonya Meselesi ile ilgili konulara sıklıkla yer verilmiştir. Örneğin Konstantinos Vakalopoulos'un Makedonya Meselesi ${ }^{40}$ adlı kitabı dönemin önemli çalışmalarından biridir. Yine 2008 yılında yayımlanan Zaman Iç̧inde Makedon Kimlikler ${ }^{41}$ başlıklı on sekiz yazarlı editoryal kitap Antik dönemden günümüze kadar Makedonya konusunu kimlik bağlamında çeşitli yönlerde değerlendiren kayda değer bir çalışmadır.

Milenyum Çağı ile adlandırılan 2000'li yıllar Yunan tarihçiliğinin hiç de yabancısı olmadığı fakat yeniden tanımlama ihtiyacı duyduğu Osmanlı/Türk kavramını bir kere daha masaya yatırmış̧ır. Zira Milenyuma varmadan önceki ilk on sene Türk-Yunan İlişkileri açısından önemli virajlara sahne olmuş ve her iki ülke dış politikasında yaşadığı "gergin" politik manevraları| tarihyazımına da yansıtmıştır. Soğuk Savaş akabinde dünya siyasetinde vuku bulan gelişmeler, örneğin ABD-Irak Savaşı, Yugoslavya'nın dağılması, Türkiye'nin Doğu Akdeniz ve Orta Doğu bölgesindeki stratejik önemini arttıran gelişmelerdir. Oysa 1991-1995 yıllarında Yunan politikasında gelişen Yugoslavya krizi, Yunanistan'1 uluslararası platformda yalnızlaştıran bir etki de yaratmıştır. SSCB ve Yugoslavya gibi çok uluslu devletlerin parçalanması Türk-Yunan İlişkileri önüne bir kere daha Kıbrıs meselesi ile ilgili konuları getirmiştir. Savaş Dönemi sonrasında ilk defa Uluslararası Toplum, ulusal toplulukların özerkliği ve federasyon çözümlerini kabul noktasında istekli görünmektedir. Sonuç itibariyle uluslararası arenada bu dönemde baş gündem maddesi Kıbrıs ile ilgili çözüm arayışlarına yöneliktir. Nisan 2004 tarihinde BM eski sekreteri Kofi Annan tarafindan hazırlanan Annan Planı, Türk-Rum kesimi halinde bölünmüş Kıbrıs Adasının bağımsız ve federal nitelikte bir devlet olarak birleştirilmesini teklif etmektedir. Ancak bu teklif, KKTC ve Güney Kıbrıs Rum Yönetiminde yapılan referandumlarda Rum tarafının ret vermesiyle hayata geçirilememiş ve akabinde de Güney Kıbrıs Rum kesimi 2004 yılında Avrupa Birliği'nin tam üyeliğine kabul edilmiştir.

2000'li yılların başında Yunan tarihçiliğinin gündemine oturan bir diğer önemli konu da Türkiye ve Yunanistan'1 neredeyse savaşın eşiğine getiren Kardak Krizi (1996), PKK terör örgütü başı Abdullah Öcalan'ın Yunanistan'a kaçak girişi (1999) ve Yunan gizli servisi tarafından Kenya'ya geçirilmesidir. Dolayısıyla bu dönemde kitapçı raflarında en çok görülen ve yayınevlerinin ekseriyetle tercih ettiği konuların başında Türk-Yunan İlişkileri ve Kıbrıs meselesi bulunmaktadır. Yunanistan'ın önemli tarihçileri ve Türkiye uzmanları gerek akademik dergilerde gerekse monografi kitaplarda konu üzerinde birçok kapsamlı çalışmalar yapmıştır. Örneğin Atina Üniversitesi'nin Siyaset Bilimi Profesörlerinden Pashalis Kitromilidis, Kıbrıs ile ilgili Yunanistan'ın en köklü akademik dergilerinden biri kabul edilen Çağdaş Konularda yazdığı “Kıbrıs'ın siyasi konumu ve Kıbrıs çözümü" ${ }^{2}$ başlıklı makalesinde mevzuyu politik ve ideolojik

\footnotetext{
${ }^{39} \Lambda$ ı́́́коs, a.g.e., s. 561-563.

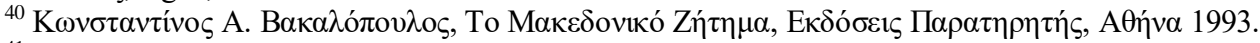

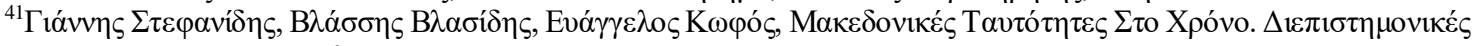

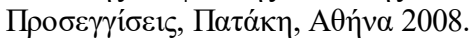

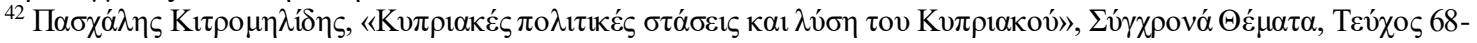

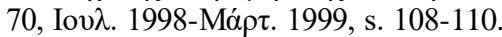


yönden derinlemesine incelemiştir. 2000 yılı ve sonrasında Yunanistan'da Türk-Yunan İlişkileri hakkında çıkan bir dizi kitaptan bazıları alt başlıklar halinde yıllara göre şöyle dağılım göstermektedir: Petros Niakouras, Uluslararası Hukuk ve Askeri Amaçlar için Deniz Alanının Kullanımı $^{43}$, Stelios Perrakis (edit), Ege. Türk Yunan Mücadelesinde Geleceğe İlişkin Çözümler ve Gelişmeler ${ }^{44}$, Grigoris Tsaltas \& Marianthi Kladi, Deniz ve Okyanusların Uluslararası Durumu ${ }^{45}$, Haritini Dipla \& Christos Rozakis (edit), Deniz Hukuku ve Yunanistan'da Uygulanışl $^{46}$, Sotiris Rizas, Türk-Yunan Illişkileri ve Ege. 1973-1976 ${ }^{47}$, Angelos Syrigos, Annan Planı. Geçmişin Mirası ve Geleceğin Umutlart ${ }^{48}$, Thanos Veremis, Türk-Yunan İlişkileri Tarihi. 1453-2006 ${ }^{49}$, Aleksis İrakleidis, Dost Görünen Komşular. Yunanistan-Türkiye. Ege'de Mücadele ${ }^{50}$, Angelos Syrigos, Türk-Yunan İlişkileri. ${ }^{51}$ Görüldüğü üzere Türkiye ve Yunanistan İlişkileri Tarihi, Kıbrıs, Ege Sorunu, Kıta sahanlığı gibi belli başlı konular her iki ülke tarihyazımında güncelliğini daima koruyan meseleler olarak kabul edilmiş ve her dönem konuyla ilgili kitaplar aktüel siyaset gölgesinde yeniden şekillenmiştir.

2000'li yılların başı Yunanistan'ın ekonomik manada kabuk değiştirdiği bir dönem olmuştur. 1 Ocak 2002 tarihinde Avrupa Birliğinin o dönem on yedi üyesinden biri olan ve 1981'den beri $\mathrm{AB}^{52}$ içinde yer alan Yunanistan, ulusal para birimi Drahmiden Euro alanının resmi para birimi Avro'ya geçmiş ve ülkede hem ekonomik hem de toplumsal bağlamda yeni bir hayat başlamıștır. Yunan tarihçiliği açısından ilgi çeken bu konu, Panos Kazakos'un Devlet ve Piyasa. Savaş Sonrast Yunanistan'da Ekonomi ve Ekonomi Politikası, 1994-2000 $0^{53}$ başlıklı kitabında Yunanistan'ın Avroya giriş serüvenini tarihi bağlamda gözler önüne seren önemli ekonomik analizlerle anlatılmaktadır. Ancak 2008 yılında değișen dünya ekonomisindeki kriz ilk dalgasını Yunanistan'a yönelttiğinde o dönem hükümetin başında bulunan Yeni Demokrasi Partisi başkanı Kostas Karamanlis bu hızlı ekonomik çöküşün baş aktörü olmak istemediği için erken seçim kararı almış ve Ekim 2009 tarihinde yapılan genel seçimleri Yunan halkına ekonomik krizin üstesinden geleceği vaadini "Paramız var!"54 sözüyle veren PASOK (Panhelenik Sosyalist

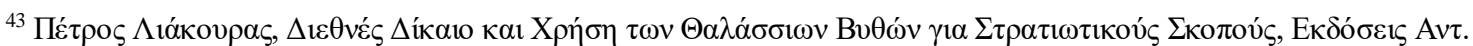

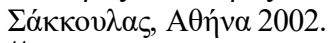

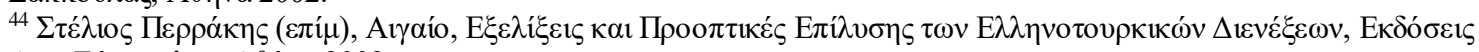

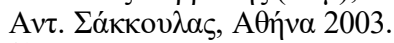

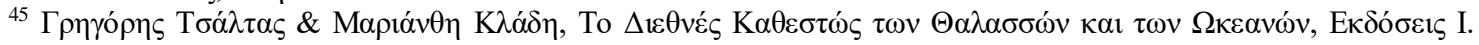
$\Sigma 1 \delta \varepsilon \dot{\varepsilon} \eta \varsigma$, A $\theta \dot{v} v \alpha 2003$.

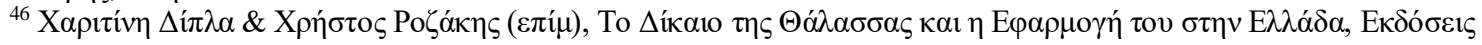

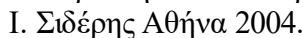

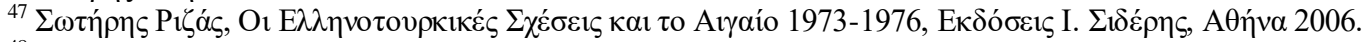

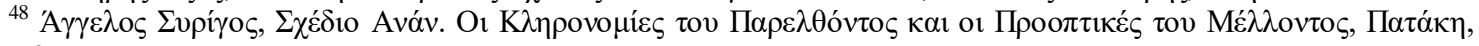
A $\theta$ ஸ́va 2006.

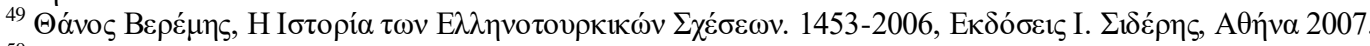

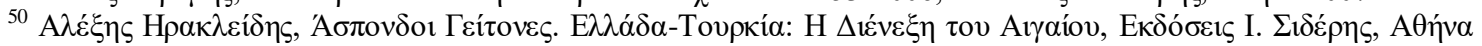
2007.

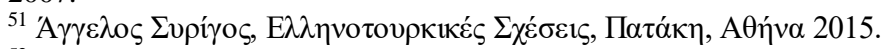

521957 yılında Roma Antlaşması ile kurulan Avrupa Ekonomik Topluluğu (AET) Belçika, Federal Almanya, Lüksemburg, Fransa, İtalya ve Hollanda'dan oluşan altı üyeli bir topluluktu. Sermaye ve iş gücünün serbest dolaştığı ortak bir pazarın oluşturulması amacıyla kurulan AET aynı zamanda topluluk içinde siyasi bütünlügün de sağlanmasını hedeflemekteydi. 1981'de topluluğa Yunanistan da dahil oldu. 1 Kasım 1993 tarihinde yürürlüğe giren Maastricht Antlaşması ile Avrupa Ekonomik Topluluğu, Avrupa Birliği adını aldı. Ayhan Kaya \& Senem Aydın Düzgit \& Yaprak Gürsoy \& Özge Onursal Beşgül (der.), Avrupa Birliği’ne Giriş: Tarih, Kurumlar ve Politikalar, İstanbul Bilgi Üniversitesi yay., İstanbul 2011, s. 1-22.

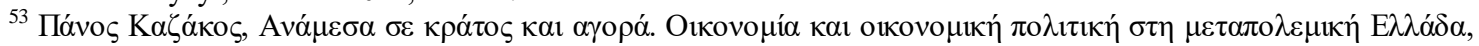

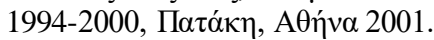

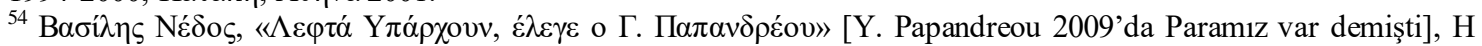

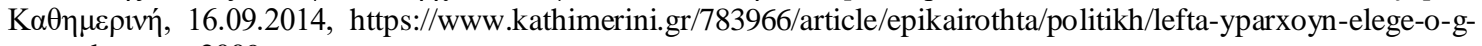
papandreoy-to-2009. 
Hareket) kazanmıştır. Fakat partinin başında bulunan Yorgos Papandreou, hükümeti kurduktan hemen sonra ekonomik açıdan önündeki trajik tabloyla da yüzleşmek zorunda kalmıştır. Gerçekte Yunanistan'ın dış borcu oldukça fazladır ve vaat ettiği gibi ülkede para da yoktur. Yeni kurulan Yunan hükümeti başta bu kötü ekonomik tabloyu değiştirmek adına belli önlemler almış olsa da kemer sıkma politikasına alışkın olmayan Yunan halkı büyük grevler, sokak gösterileri ve çatışmalarla karşı duruş sergilemiştir. Üstelik dış borcunu ödeyemeyen Yunanistan, dış devletlerden yeni borç da sağlayamamıştır. Böyle bir sonuç zaten kötü giden Yunan ekonomisinin iflasını da beraberinde getirmiştir. Neticede Yunanistan'ın içinde bulunduğu bu trajik durum onu IMF’nin (Uluslararası Para Fonu) kapısına dayandıran süreci de başlatmış olur.

23 Nisan 2010 tarihinde Papandreou, Meis adasından yaptığı açıklamada Yunanistan'ın ciddi bir ekonomik kriz içinde olduğunu ve bu krizin ancak IMF, European Central Bank ve Avrupa Birliği üçlüsünün oluşturduğu TROYKA (Avrupa Birliği-Avrupa Merkez Bankası ve Uluslararası Para Fonu) ile aş1labileceğini kamuoyuna duyurur. TROYKA, devlet harcamalarının düzene konması yönünde ciddi önlem paketleri hazırlamıştır. Yunanistan ekonomisindeki bu "sonun başlangicı" ülkede yeni bir kabuk değiştirme sürecini de beraberinde getirir. İşsizlik artar, kişi başı milli gelirde düşmeler yaşanır, harcamalar azalıp iflaslar baş gösterir. Tüm bu kaos ortamı Papandreou hükümetinin iyice güç kaybetmesine neden olur. Yine de tüm alınan önlem paketleri, uygulanan ağır tedbirler ekonomik göstergelerin başarılı bir seyir izlemesine katkıda bulunamaz. Mihalis İgnatiou tarafindan kaleme alınan TROYKA, Felakete Giden $Y_{o l} l^{55}$ başlıklı çalışma da bu dönemde ülkedeki dış güçlerin Yunan ekonomisine ve siyasetine doğrudan müdahalesini anlatan çarpıcı bir çalışma olarak raflarda yerini alır. Siyasi tarihinde toplam yedi kez ekonomik iflas görmüş Yunanistan'ın 2009 sonrasında içine düştüğü iktisadi bozulma Yunan tarihçiliğinin de ilgisini doğrudan bu yöne çevirmiştir. Ülkenin önde gelen yerli ve yabancı tarihçileri Yunan İktisat ve Siyasi Tarihini kronolojik sırada deşifre eden önemli çalışmalara imza atarlar. Örneğin Pashalis Kitromilidis'in Çağdaş Yunanistan'da Tarihyazımı, 1833-2002 ${ }^{56}$, Aleksis Frangiadis'in XIX. ve XX. yüzyılda Yunan Ekonomisi ${ }^{57}$ ve Mark Mazower'in Yunanistan. İki Savaş Arasında Ekonomik Kriz ${ }^{58}$ adlı çalışmaları konuya $1 s ̧ 1 k$ tutan önemli kitaplardan bazılarıdır.

Ekonomik krizle mücadele eden Yunanistan'ın aldığı her yeni önlem paketi Papandreou'nun başında bulunduğu PASOK için başka bir çıkmaz ve kan kaybı sebebidir. Nitekim 6 Kasım 2011 tarihinde Papandreou ve Nea Dimokratia (Yeni Demokrasi) partisinin yeni başkanı Antonis Samaras kurdukları ortak koalisyon ile ülke yönetimini beraber yürütme kararı alır. Yeni kurulan hükümet de ekonomik anlamda eski tedbirleri aynı düzende uygulamaya devam eder. Ancak bu yeni oluşum, halkı ekonomik düzeyde rahatlatan bir çözüm olmadığından Yunanistan 6 Mayıs 2012 tarihinde yeniden seçime gider. Yunan tarihçiliğinin bu dönemde en baş gündemi ise Yunanistan'ın kuruluşundan bu yana yaşadığı siyasi ve ekonomik krizlerdir. Söz konusu dönemde konuyla ilgili birçok kitap Yunanistan'ın önde gelen yayınevlerinden çıkarılır. Örneğin Stavros Lygeros'un Hırsız İktidardan Iflas Sürecine ${ }^{59}$ adlı çalışmasında sadece ekonomik krizin sebepleri irdelenmez aynı zamanda siyasilerin de söz konusu hezimetteki sorumluluğu satirik bir başlık altında sorgulanır. Yunanistan'ın ekonomik krizini inceleyen bir diğer önemli çalışma da Petros Papasarantopoulos tarafindan kaleme alınan Yunanistan Krizindeki Mitler ve Stereotipler ${ }^{60} a_{1}{ }_{1}$ kitaptır. Yine Georgios Dertilis'in Yedi Savaş, Dört İç Savaş, Yedi Ekonomik

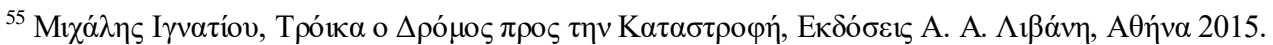

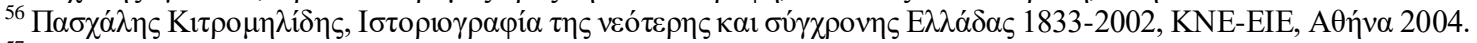

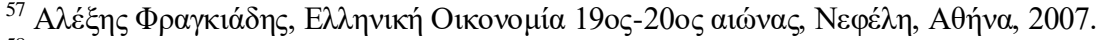

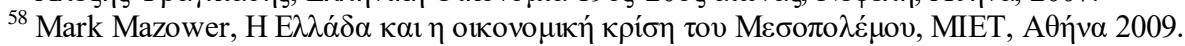

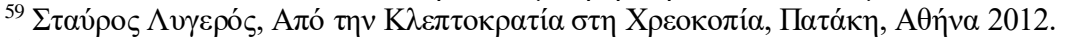

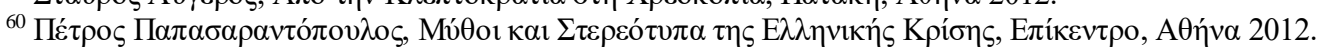


Iflas $^{61}$ başlıklı kitabı dönemin siyasi ve ekonomik karmaşasını tarihi atıflarla irdeleyen bir diğer önemli çalışmadır.

Yunanistan'in siyasi görüntüsü bu seçimin akabinde tamamen değişmiştir. Halk, PASOK ve Yeni Demokrasi Partisini adeta cezalandırırcasına oy oranlarını toplamda yüzde 30'a düşürmüştür. Bu siyasi tabloda Yunan halkı TROYKA ile işbirliği içinde olan diğer partilerin de oylarını azaltmıştır. Seçimlerde TROYKA karşıtı politika izleyen partiler ise oy oranlarını beklenmedik düzeyde arttırmışlardır. Bu partilerin başında da radikal sol parti SYRIZA bulunmaktadır. SYRIZA'nın başkanı Aleksis Çipras partinin genç ve dinamik lideri olarak Yunanistan'ın $\mathrm{AB}$ üyeliğine Avro bölgesinde kalarak devam etmesini ancak bu üyeliğin ağır koşullar kabul edilmeksizin sürdürülmesini destekleyen bir lider görüntüsü çizmektedir. Böylece SYRIZA bu döneme kadar yüzde 2 ile yüzde 5 arası değişen oy potansiyelini son seçimlerde yüzde 17 oy oranına yükseltir. Bu öngörülmeyen yükselişte SYRİZA, Yunanistan'da ikinci parti konumuna gelir ve bugüne kadarki tüm seçimlerin görüntüsünü değiştirmekle kalmayıp aynı zamanda siyasi bir ezberi de bozmuş olur. Zira Yunan halkı için ekonomik buhrandan çıkmanın tek adresi başından beri Memoranduma karşı geliştirdiği söylemlerle ön plana çıkan SYRIZA partisidir. Partinin lideri Aleksis Çipras verdiği her beyanatta TROYKA ile iş birliği içinde olan siyasi partilerin ihanet içinde olduğunu ve ekonomik baskının hiçbir şekilde kabul edilemeyeceğini vurgulamaktadır. Özellikle ekonomik kriz sonrasında Yunan kolektif belleğinde “Almanya İmparatorluğu” olarak görülen Avrupa Birliği, Yunanistan'ın sadece ekonomik bağımsızlığını ele geçirmekle kalmamış aynı zamanda ülkenin milli onurunu da hiçe saymıştır. Almanya eksenli gördüğü Avrupa'ya karşı Çipras'ın geliştirdiği söylem ve karşı duruş, Yunan tarihçiliğinde yeniden Alman İşgal yıllarını ön plana çıkartır. Örneğin 2010 yılında raflarda yerini alan Yunanistan'da Alman İsali ${ }^{62}$ başlıklı derleme kitapta Alman işgal dönemi tarihsel boyutlarıyla incelenmiştir. Yine bu dönemde Hitler'in zalimliği ile Merkel'in zulmü arasında paralellik kurulan birçok farklı makale yayımlanmıştır. Sağ görüşlü popüler tarih dergisi Ardin' in Mayıs-Haziran 2013 sayısında, Yunanistan'daki Alman işgal yıllarını hatırlatan özel bir dosya hazırlanmıştır. Alman Avrupası: Alman İsgalini boykot edelim - Yeni bir üretim modeline ithaf olunur $^{63}$ başlıklı sayıda Orta Avrupa'daki Alman hegemonyası sivri bir dille eleştirilir. Bu dönemde basın organlarının neredeyse tamamında (gazete, televizyon, sosyal medya) konuyla ilgili tartışmalar gündeme getirilir. Dolayısıyla Yunanistan'daki kitabevlerinin raflarında da Avrupa Birliğini sorgulayan, Yunanistan'ın AB sürecini anlatan yeni kitaplara yer verilir. $\mathrm{Bu}$ kitaplar arasında Dionysios K. Magliveras'ın Son ve Başlangıç. Bir geçiş döneminin denemeleri ${ }^{64}$ ve Yunanistan'da 2015-2018 yılları arasında Dışişleri Bakanı olarak görev yapan Nikos Kotzias'ın Borç sömürgesi Yunanistan. Avrupa İmparatorluğu ve Alman Önceliğ ${ }^{65}$ adlı çalışmaları dönemin ruhunu yansıtması açısından önemli eserlerden bazılarıdır.

2010 senesinden sonra ülkede baş gösteren ekonomik krizin tsunami etkisi ilk büyük dalgasını memur ve emekliler üzerine vurmuştur. Ekonomik krizden sonra hükümet tarafından alınan tüm önlem paketleri ve kemer sıkma politikaları Yunanistan için sancılı bir süreci de beraberinde getirir. Ülkede değişen dengeler (sık hükümet değişimi, AB'nin ekonomik desteğini çekmesi, sokak gösterileri, polisle çatışma, TROYKA kriterleri vb.) ve ekonomide yaşanan darboğaz,

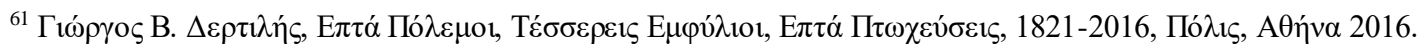

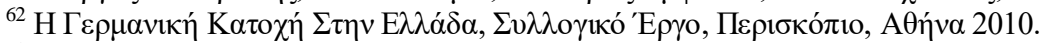

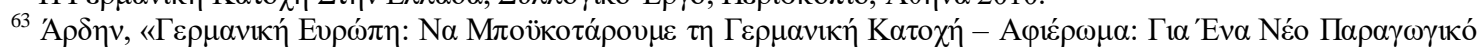

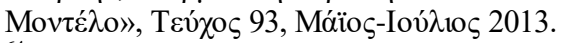

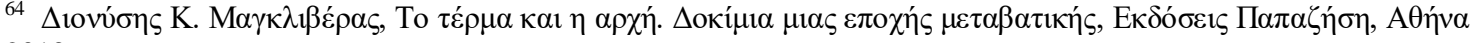
2013.

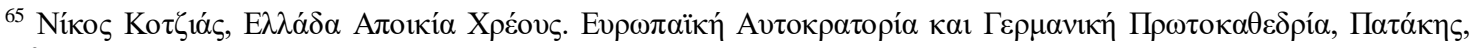
A $\theta$ ท́va 2013.
} 
Yunanistan'da ekonomik krizin dışında aynı zamanda sosyo-psikolojik bir krizin yaşanmasına da olanak sağlar. Halk, psikolojik anlamda yorgun, umutsuz ve mutsuzdur. Ülkeye hâkim olan bu karamsar hava aslında Modern Yunan Tarihinin hiç de yabancısı olmadığı bir başka tarihi tekerrür sayılabilir. 1919 yılında Yunanistan'ın peşine düştüğü Megali İdea'nın 1922 yılında Anadolu'da büyük bir yenilgiyle sona ermesi ve sonrasında ülkede yarattığı olumsuz atmosfer, kriz sonrasında Yunanistan'da yaşanan genel havayla benzer özellikler göstermektedir. Özellikle ekonomik krizin neden olduğu ruhsal çöküntü ile beraber Yunanistan'da yüzde 40 oranında intiharlar artar. Bu intiharların en trajik olanı 4 Nisan 2012 tarihinde 77 yaşındaki emekli eczacı Dimitris Hristoula'nın Yunan Parlamentosunun önündeki Sindagma meydanında, onca insanın önünde, tüfekle kendisini vurmasıdır. İntihar etmeden önce etrafında toplanan kalabalığa "çocuklarıma borç para bırakma niyetinde değilim" demesi aslında ülkedeki ekonomik yükün ve çöküntünün ağırlığının en reel ispatıdır. Nitekim bıraktığı mektupta da halkın bu tepkisinin siyasilere yöneltilmiş bir öfke nöbeti ve protesto girişimi olduğu açıkça görülmektedir.

Krizin kendisini en fazla gösterdiği yerlerden bir diğeri de eğitim alanıdır. Okullarda öğrencilere bedava dağıtılan kitaplar kriz sonrası yerini fotokopilere bırakmış ve 1sınma giderleri kesilmiştir. Üstelik bazı öğrenciler yetersiz beslenmenin verdiği olumsuz etkiyle okullarda baygınlık geçirmiştir. Çalışanların ücretleri yarı yarıya düşürülmüş, faturalara ciddi vergiler yansıtılmış, maaşlar ödenememiş ve işten çıkarılmalar başlamıştır. Bu süreç beraberinde eğitimin istikrarlı yürütülmesini de engellemiştir. Bunun en somut örneğini Atina Üniversitesi'nin hükümet kararıyla bir dönem eğitime ara vermesi oluşturmuştur. Yunan devlet kanalı ERT (Yunan Radyo Televizyonu) de kriz ile birlikte varlığını sürdüremeyip 21 Haziran 2013 tarihinde kapatılır. Yunanistan, ilk defa, 3 ay süreyle devlet kanalı faaliyetini durdurur. Her ne kadar sonrasında EDT (Yunan Halk Televizyonu) adı verilen ve ilk dönemlerde sadece belli saatlerde yayın yapan yeni bir devlet kanalı açılmış olsa da, devletin iletişim kanalı eski gücünü ve niteliğini çoktan yitirmiştir. 2010-2015 yılları arasında Yunanistan her anlamda zor bir dönemden geçer. Krizin etkileri her alanda ve en ağır şartlarda kendisini göstermiş ve toplumun psikolojik sınırları alt üst olmuştur. Nitekim Hristos İkonomou tarafindan kaleme alınan ve 2010 yılında Yunanistan'da en iyi hikâye kitabı seçilerek devlet ödülü kazanan Göreceksin, bir şeyler olacak $^{66}$ adlı kitap, kriz Yunanistan'ındaki insan portrelerini, buhranları ve insanların ruhsal çöküntülerine dair psikolojik analizleri okuyucuya detaylı bir biçimde sunmaktadır.

2012 yılından sonra tırmanışa geçen SYRIZA, Ocak 2015'den Temmuz 2019'a kadar Yunanistan'ın yönetiminde söz sahibi olan bir parti konumuna geçer. Ancak iç politikasında seçim vaatlerinin tam aksine IMF ve TROYKA'nın yaptırımlarına karşı güçlü bir duruş sergileyemez. PASOK ve Yeni Demokrasi Partisi gibi SYRIZA da Avrupa Birliği karşısında başarılı bir siyaset izleyememiştir. SYRIZA Hükümeti, Yunanistan'a borç verenlerle bir dizi görüşmeler başlatmış ve her görüşmenin sonunda yeni bir çıkmazla yüzleşmek zorunda kalmıştır. SYRİZA Hükümetinin Ekonomi Bakanı Yannis Varufakis' in AB, TROYKA ve IMF'ye karş1 gösterdiği direniş dış politikada beklenen yeri de sağlayamamıştır. Aynı zamanda Ekonomi Profesörü olan Varufakis'in Yunanistan'a ekonomik destek arayışlarını sürdürdüğü sırada çıkardığı Kızıma Ekonomi Sohbetleri ${ }^{67}$ adlı kitabı dönemin en çok satanları arasında zirveye oturduğu gibi Yunan halkına basit ifadelerle krizin sebeplerini de anlatmaya çalışmaktadır. Varufakis'e göre Yunan halkının içine düştüğü ekonomik buhranın nedeni Kapitalist dünya düzeninin bir sonucudur. Nitekim Varufakis'in 2017 yılında çıkardığı Yenilmeyen Kaybedenler ${ }^{68}$ adlı kitapta da SYRIZA'nın seçim vaatlerine paralel düzeyde bir alg1 ortaya konulmak

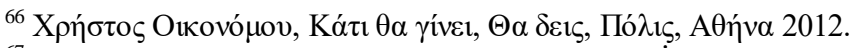

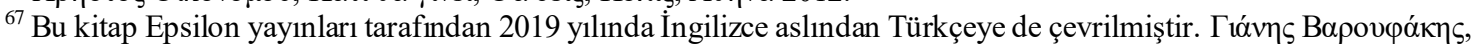

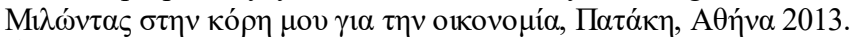

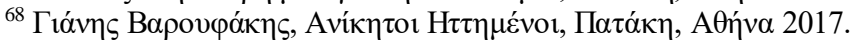


istenmektedir. Yunanistan her ne olursa olsun, yaşadığı buhranı, AB'ye karşı her zaman dik ve onurlu durarak atlatmalıdır. Bu dönemde Yunan tarihçiliğinin gündeminde de ekonomik kriz ile birlikte radikal sol hükümet SYRIZA ve onun politik süreci bulunmaktadır. Örneğin Petros Papakonstantinou'nun Kriz, Sol, İktidar. Büyük Klşkırtma ${ }^{69}$ adlı kitabı dönemin ruhunu yansıtması açısından dikkate değerdir.

Kısaca Yunanistan'da 2015 yılının tek gündemi ekonomidir. İflasın eşiğinde bir ülkede ilk defa radikal sol parti, hükümeti kurmuş ve kapitalizme karşı mücadele edeceği sözünü vermiştir. Çünkü yeni hükümet ekonomik krizin en büyük mümessilini “kan emici” saydığı Avrupa'nın kapitalist dişlilerinde aramaktadır. Üstelik Yunan İş Savaşı süresince Amerika ve Britanya'nın müdahalesiyle sol kanadın yıkılışına karşı SYRİZA, yaklaşık yüz sene sonra, tarihi bir de javu ile yeniden mücadele etmektedir. Ancak ne seçim vaatleri ne de Ekonomi Bakanı Varufakis'in IMF'ye karşı dayatmaları sonuç vermez. 25 Haziran 2015'de AB yetkilileriyle uzlaşmaya varan SYRİA, Avrupa kurumlarının önerdiği anlaşmayı kabul edip etmeme konusunda halkın insiyatifine başvurur. 5 Temmuz referandumunun sonucunda Yunan halkı yüzde 61,31 oranında AB yaptırımlarına Hayır der. Ancak Evet-Hayır Referandumunun ardından 13 Temmuzda SYRIZA ve $A B$ yetkililerin bir anlaşmaya varması ülke genelinde büyük tepkiyle karşılanır. Üstelik SYRIZA Partisi kendi içinde de bazı milletvekillerinin istifasıyla kan kaybetmiştir.

2015 sonrasında SYRİA'nın Yunanistan siyasetinde azalmaya başlayan etkinliği ve halkın desteğini kaybetmesi 12 Haziran 2018 tarihinde "ihanet" ile özdeşleştirilecek yeni bir anlaşmanın kabulüyle nihai sona ulaşır. Yunanistan Başbakanı Aleksis Çipras ve Makedonya Başbakanı Zoran Zaev arasında Makedonya'nın isim sorununun çözümüne yönelik Prespa Anlaşması'nın imzalanması ülke genelinde SYRIZA aleyhine çıkan sesleri daha fazla güçlendirmiştir. Öyle ki Prespa Anlaşmasından ötürü Yunanistan'da siyasi partilerde bölünmeler yaşanmış ve Bağımsız

Volume 12 Issue 6

December 2020

Yunanlar Partisi (ANEL) hükümetten çekilerek koalisyonu bozmuştur. Başbakan Çipras'ın meclisten talep ettiği güvenoyu çeşitli partilere üye milletvekillerinin desteğiyle kazanılmış ve Çipras bu sayede başbakanlık görevinde kalabilmiştir. Dolayısıyla ülkede hem siyasal hem de toplumsal krize sebep olan Prespa Anlaşması Yunan tarihçiliğinin baş gündeminde yerini almış olur. 2018-2019 yılları arasında pek çok önemli Yunan tarihçi Makedonya konusunu ve Prespa Anlaşmasını konu alan kitaplar yayımlar. Örneğin Kostis Karpozilos \& Dimitris Christopoulos'un, 10+1 Soru ve Cevapta Makedonya Sorunu ${ }^{70}$, Aleksis İrakleidis'in, Makedonya Sorunu 1878-2018. Ulusal İddialardan Çatışan Ulus Kimliklerine ${ }^{71}$ Nikolaos Mertzos'un, Makedonya Meselesi ${ }^{72}$ ve Angelos Syrigos \& Evanthis Chatzivasileiou'nun, Prespa Anlaşması ve Makedonya Sorunu ${ }^{73}$ adlı kitapları konuyla ilgili önemli çalışmaların başında gelmektedir.

Tüm bu sancılı süreçlerin sonunda Yunanistan'da yapılan 7 Temmuz 2019 genel seçimlerinde yüzde 39,85 oy oranıyla hükümeti kurma görevi yeniden Yeni Demokrasi partisine verilir. Böylece Yunanistan'da sol parti hükümeti dönemi sona ererek bir devir daha kapanmış olur. Siyasi dönüşümlere kayıtsız kalamayan Yunan tarihçiliğinde de 2015-2019 yılları arasında hükümetin başında bulunan SYRIZAA Partisi ve Aleksis Çipras'ın başbakanlık dönemi iyisiyle-

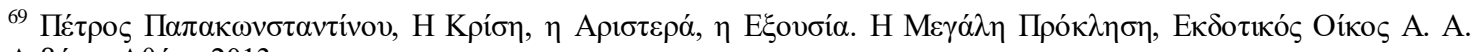
$\Lambda 1 \beta \alpha ́ v \eta$, A $\theta \dot{v} v \alpha 2013$.

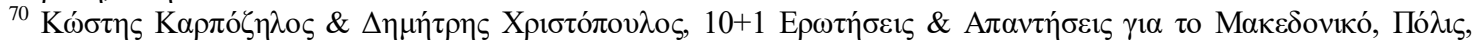
AӨท́va 2018.

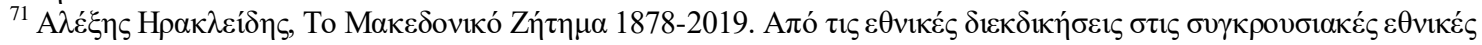

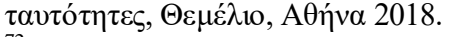

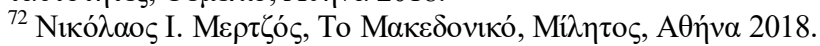

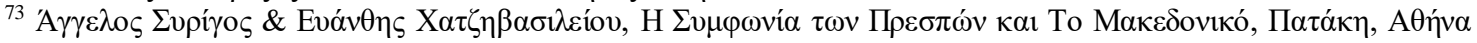
2019.
} 
kötüsüyle masaya yatırılıp irdelenmeye başlar. Yunanistan'ın Pataki, Epikentro, Themelio gibi köklü yayınevlerinden radikal sol parti SYRIZZA ve Aleksis Çipras dönemini sorgulayan ve hatta eleştiren kitaplar yayımlanır. Örneğin Georgios Kontogiorgis'in Yeni Să̆ olarak SYRIZZA Solculart. Solun Muhafazakâr Yasası ${ }^{74}$, Sakis Moumtzis'in SYRIZA. Aldatanlar ve Aldatılanlar $^{75}$, Lefteris Kousoulis'in SYRIZZA. Bir Politik Olay ${ }^{76}$, Kostas Douzinas'ın Üniversite Kürsüsünden Milletvekili Siralarına. Sol Hükümet Günleri ve Ícraatlart ${ }^{77}$, Ariste1dis Baltas'1n Parantez İçi. Radikal Sol Yönetimi. Illk Dönem (25 Ocak 2015-21 Ağustos 2018) ${ }^{78}$, Sakis Moumtzis'in SYRIZZA. Barbarlığın Sonu ${ }^{79}$ ve Giannis Balabanidis'in (edit) Süreç İçinde Bir Siyasi Parti SYRIZZA. Protestodan Yönetime ${ }^{80}$ adlı kitapları son dönem Yunan siyasetine 1şık tutan çalışmalardan sadece bir kaçıdır.

2019 yılı Yunan siyasetinde olduğu gibi Yunan tarihçiliğinde de bir mana da "throw back" şeklinde tanımlanabilecek bir noktaya gelmiştir. "Yüz sene önce bugün” yıldönümleri içinde 1919 İzmir'in İşgali, 1922 Küçük Asya Bozgunu, 1923 Lozan Antlaşması ve Türk-Yunan Zorunlu Nüfus Mübadelesi gibi konular büyük önem arz eder. Hatta Yunan ulusunun Osmanlı hakimiyet döneminden kurtulmasını simgeleyen 1821 yılı da Yunan bağımsızlığının iki yüzüncü yılı kutlamalarında tarihçilerin mesaisini konu üzerinde yoğunlaştırmıştır. Yunanistan'daki üniversitelerin Tarih bölümleri Mora İsyanının iki yüzüncü yılı nedeniyle birçok sempozyum, panel ve editoryal kitap hazırlamaya başlar. Yine bu dönemde İzmir ve Anadolu'nun Yunan orduları tarafından işgal edilme sürecini kaleme alan birçok yazar aynı zamanda Yunan irredantizminin sembolü "Megali İdea"yı da yeniden masaya yatırarak farklı bir bakış açısıyla yorumlar. Sotiris Rizas'1n Megali İdea 'nın Sonu. Venizelos ve Anadolu'da Antivenizelizm ${ }^{81}$ adl $_{1}$ kitabı Yunan ordusunun Anadolu işgalindeki başarısızlığını Yunan tarihçiliği gözünden değerlendiren önemli bir çalışmadır. Son dönem Yunan tarihçiliğinin en çok ele aldığı konulardan bir diğeri de Ulusal Bölünme konusudur. Özellikle SYRIZA döneminde yaşanan Evet-Hayır Referandumu ile 1915-1922 yılları arasında yaşanan polarizasyonun paralellik göstermesi birçok tarihçinin de ilgisini çekmiştir. Örneğin Sotiris Rizas'ın Venizelizm ve Antivenizelizm. Ulusal Bölünmenin Başlangıcında $(1915-1922)^{82}$ ve Georgios Mavrogordatos'un 1915. Ulusal Bölünme ${ }^{83}$ adlı kitapları Büyük Savaş yılları sırasında başlayan ve Yunan İç Savaşına kadar devam eden Yunanistan'daki Venizelist ve Kralcı bölünmesini ayrıntılarıyla işlemektedir. Yine Mavrogordatos'un 1915. Ulusal Bölünme kitabının devamı olarak kaleme aldığı 1922 Sonrası. Ulusal Bölünmenin Devami ${ }^{84}$ adlı çalışmasında Küçük Asya Bozgunu sonrasında Yunanistan'da yaşanan siyasi ve sosyal bunalımlar irdelenmiştir. Thanos Veremis'in Eleftherios Venizelos. Fizibilite Vizyoneri ${ }^{85}$ ve Stathis Kalyvas'ın Felaketler ve Zaferler. Çağdaş

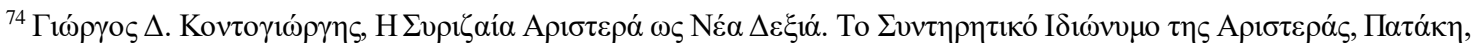
A $\theta$ ท́va 2016.

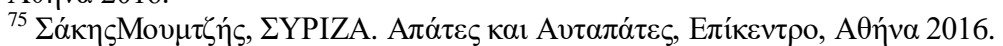

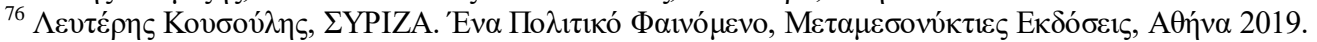

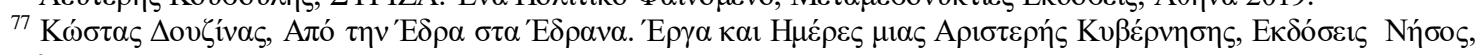
A $\theta$ ท́va 2019.

${ }^{78}$ A

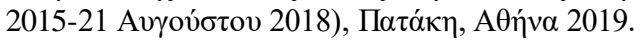

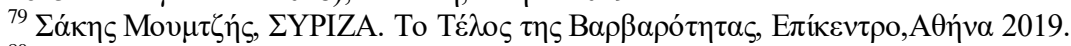

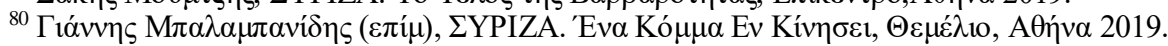

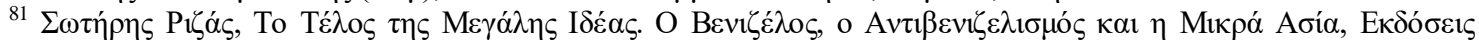

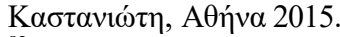

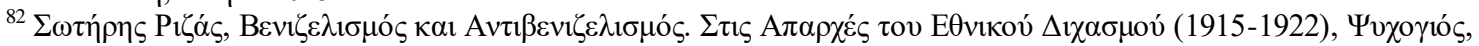
A $\theta \dot{v} v \alpha 2019$.

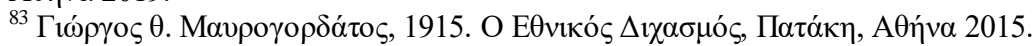

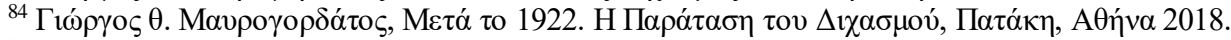

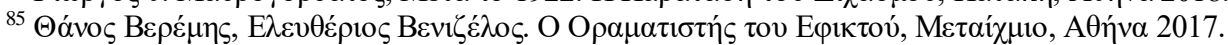


Yunan Tarihinin Yedi Döngüsü̈ ${ }^{86}$ başlıklı çalışmaları dönemi aydınlatan diğer nitelikli eserlerdir. 2019 yılında kapsamlı bir çalışmaya imza atan Yunan tarihçi Antonis Liakos da Yunanistan'ın $X X$. Yüzyllı ${ }^{87}$ adlı kitabında ulusun kuruluşundan günümüze kadarki tüm Yunan Tarihini derinlemesine incelemiştir. Son dönem Yunan tarihçiliği konusunda hazırlanmış en kapsamlı eserlerden biri sayılan bu kitap Yunanistan'daki kitapçılarda da "çok satılanlar" listesinde kendine önemli bir yer açmıştır.

Yunan tarihçiliğinin bir diğer önemli ayağı sayılan akademik tezlerde ise 2000-2019 yılları arasında Türkiye ile ilgili çalışmalar dikkat çekmektedir. Tezlerin içeriği daha çok son dönem siyasetine bağlı gelişen Türk-Yunan İlişkileri, Batı Trakya'daki Etnik ve Dini Kimlikler, Kürt Sorunu, Türkiye'nin Orta Doğu Politikası, Ders Kitaplarında Öteki ve Kimlik, Türkiye ve İslam, Kıbrıs Sorunu, İstanbul Rumları, Ege Adaları, Osmanlı'da Rum Azınlıklar, Türkiye'de Siyasi Partiler, Ders Kitapları ve Eğitim gibi konulardan oluşmaktadır. Görüldüğü üzere Yunan popüler tarihçiliğinde ele alınan her konu aslında Yunan akademik tarihçiliğinde de dikkat çeken meselelerdir. Yunanistan'da Epikentro ve Periplous gibi yayınevleri de bu türden akademik çalışmaların kitaplaştırılmasına gerekli desteği sağlamıştır. Diğer taraftan Yunanistan'daki bazı yayınevleri konu bağlamında daha lokal sınırları tercih etmiş ve sadece belli temalar üzerinde kitaplar çıkarmayı hedeflemiştir. Örneğin Tsoukatos yayınevi daha ziyade Yunanistan'a göçen Rumlar hakkında sosyal ve kültürel çalışmalara ağırlık veren eserler üretmektedir. Dolayısıyla Türkiye ve Osmanlı ile ilgili konular gerek akademik gerek popüler yayınların tamamında okuyucunun ilgisini çekmesi nedeniyle birincil sırada yer almıştır.

Son dönem Yunan tarihçiliğinde en çok tartışılan konulardan biri ise Tarih biliminin tam olarak nereye ve kime ait olduğu sorunsalı üzerinedir. Bilhassa "tarihi sadece tarihçiler mi konuşmalı" sorusu 2016 y1lından itibaren Yunan tarihçiliğinin baş gündeminde yer alan meselelerinden biridir. Bu konuda Yunanistan'daki iki farklı görüş birbiriyle adeta kıyasıya mücadele halindedir. Tarihçiler, yalnızca mesleği tarihçi olanların tarihi konularla ilgili görüş bildirmesi gerekliliğini savunurken -çünkü tarih konusunda yetkin olan grup yalnızca tarihçilerdir ve konuyla ilgili en geniş bilgiye yine onlar sahiptir-bir başka grup da bu görüşü "elitist" bularak her bireyin, her kurumun ve hatta Yunanistan'da eğitim konusunda etkinliği tartışılmaz bir güç olan kilisenin de tarihi meseleler hakkında görüş bildirme hakkına sahip olduğunu ifade etmektedir. Nitekim söz konusu görüşün temsilcileri açısından tarih asla ufak bir zümrenin bilimi olamaz. Tarih, halka aittir ve yine halk tarafından savunulması gereken bir yurttaşlık ödevidir. Bu konuyla ilgili en ateşli tartışma 2006 y1lında Selanik Aristoteles Üniversitesi’nden Prof. Dr. Maria Repousi ve ekibi tarafından yazılan Çağdaş Dönemler adlı ilkokul altıncı sınıf tarih kitabına yöneliktir. Kitabın ulusal geçmiş, ulusal bilinç ve ulusal kimlik konularında yetersiz olduğunu düşünen birçok Yunan vatandaşı oluşturduğu kamuoyu ve imza kampanyası ile kitabın acilen okullardan geri toplatılmasını talep etmiştir. ${ }^{88}$ Toplumun her meslek grubundan ve sosyal sınıfindan katılım sağladığı bu tartışmaya Panteion Üniversitesi Siyaset Bilimi ve Tarih Bölümü hocalarından Prof. Dr. Christina Koulouri, Yunanistan'ın önde gelen gazetelerinden biri olan Vima'ya verdiği sert ve ironik demeciyle şu sözlerle dahil olmuştur:

"Söz konusu ders kitabının toplatılmasını isteyen ve besiciler, ev hanımları, askerler, Ortodoks Halk Uyanışı Partisinin merkez kurul üyeleri ve eski Cumhurbaşkanı Christos Sartzetakis tarafından imzalanan bir metin ortada dolaşıyor. İmzacılar arasında tarihçilerin azlığı tesadüfi bir durum

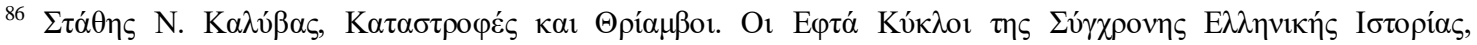

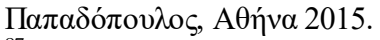

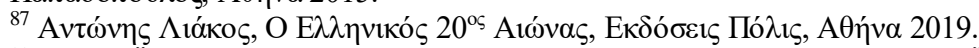

88 Esra Özsüer, "Tarihin resmi ideoloji Tarafindan Tahrifatına Bir Örnek: Yunanistan", Turkish History EducationJournal, Fall 2018, 7(2), s. 498-501.
} 
olamaz. Metinden de anlaşılacağı üzere bir ev hanımının ya da imza için Almanya'dan ortaya çıkan bir işçinin bilimsel ve pedagojik onay almış bir kitabı okuyup üstüne de görüş bildirmesi kabul edilebilir bir şey mi? ${ }^{89}$

Yunan tarihçi Christina Koulouri'nin söz konusu beyanatı tarihin sadece geçmiş konularla ilgili her tür donanıma sahip olan tarihçilerin işi olduğu fikrini destekler niteliktedir. Ancak XXI. yüzyılın internet çağı olduğu düşünüldüğünde halkın her kesimden üyesi popüler tarihçiliğe katk1 sunan görüşlerini ifşa ederek bir bakıma tarihçilerin de asli rolünü değiştirebilmiştir. Özellikle tüm dünyada olduğu gibi Yunanistan'da da sosyal medyanın yaygınlaşması sonucunda birey herhangi bir denetim olmaksızın istediği görüşü doğru ya da yanlış, gerçek ya da hayal ürünü olsun dile getirmeye başlamıştır. Mesela XV. yüzyıldan önce el yazmaları çok meşakkatli olduğundan tarih yazan çok az tarihçi vardır. Dolayısıyla yazılanları okuyanların sayıları da buna paralel biçimde az sayıdadır. Öte yandan matbaanın icat olması ile birlikte tarihi yazanların sayısı yine fazlalaşmamıştır ancak bu sefer de okuyucu kitlesi çoğalmıştır. Benedict Anderson'un ifadesiyle "matbuat kapitalizmi" dünya üzerinde oluşan yeni düzenin de söz sahibidir. Oysa günümüz dijital çağında herkes istediği her fikri kolayca ve hatta sansürsüz yayımlayabildiği için internete erişim gerek Yunanistan'da gerekse diğer ülkelerde artık gündelik hayatın bir parçası durumuna geçmiştir. Özellikle tarihçi kimliklerin dışındakiler de tarih ile ilgili yorum yapabilme hakkını kendinde bulmuş ve aynı dijital platformda yer alan bu ifadeler, tarihçilerin yaptığı yorumlardan da çoğu zaman ayrı tutulmamıştır. Öyle ki hangi yorumun daha baskın olduğunu dijital platformdaki "like" veya "tıklanma" sayısı belirlemektedir. Üstelik kimin takipçi sayısı fazlaysa o görüşe ya da o kişiye çok daha fazla itimat ediliyor yargısı oluşmuştur. Sosyal medyada sıklıkla tekrarlanan ve bilhassa toplumun reflekslerini/hassasiyetini anlama hususunda yeterli doneler sunan en temel mesele Yunan tarih inşasını yıkma girişiminde bulunan tarihçiler ve siyasilerdir. Örneğin Prespa Anlaşmasına destek veren akademisyenlere, siyasilere ya da sıradan vatandaşlara sosyal medya üzerinden "tarihimizi çalmalarına izin vermeyin" sloganıyla linç girişiminde bulunulmuş ${ }^{90}$ ve tarihe "öteki" cepheden de bakmak isteyen tarihçilere "tarihimizi yeniden üretmenize izin vermeyeceğiz" sözleriyle karşı savaş açılmıştır. ${ }^{91}$

Sonuç olarak XX. yüzyılın son yirmi beş yılında Yunanistan'da tarih kitaplarındaki baskı sayısı dokuz kat artmıştır. Bu yükseliş XXI. yüzyılın başlarında da devam etmiş ve Tarih bilimi toplum bilimleri arasında en fazla rağbet gören bölümlerden biri olmuştur. ${ }^{92}$ Dolayısıyla Yunan tarihçiliği artan bu ilgi ile beraber farklı görüşlere sahip modernist tarihçilere de kapılarını aralayabilmiştir. Son dönemlerde sayıları hızla artan ve yenilikçi bakış açısıyla ulusal tarihi yeniden yorumlayan bilim insanları ortaya koydukları eserlerle Yunan tarihçiliğinde bilinen/ezberlenen kalıpların dışında farklı görüşler bildirmeye başlamıştır. Aslında Yunan Tarihinde Paparrigopoulos çizgisinin dişındaki bu değişimi ilk defa tarihçi Nikos Svoronos'un Çağdaş Yunan Tarihinin Yeniden Gözden Geçirilmesi ${ }^{93}$ adlı kitabı başlatmıştır. Bu kitabın en önemli özelliği ulusa değil topluma, olgulara değil ekonomik ve toplumsal gelişimlere öncelik vermesidir. Svoronos'un 1953 yılında Paris’te, sürgünde yaşadığı dönemde kaleme aldığı Çağdaş Yunan Tarihinin Yeniden Gözden Geçirilmesi adlı kitabı Yunanistan'da ilk defa 1975 yılında, yani Askeri Cunta sona erdiğinde, basılabilmiştir. Çünkü Yunan uyruğundan çıkarılan

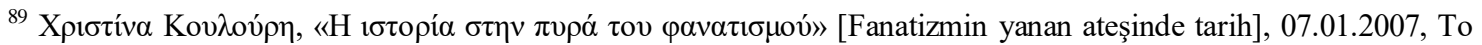

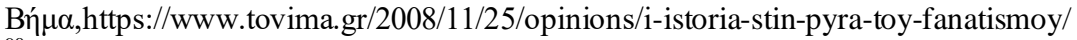

90 Ayrica daha önce Makedonya isim meselesi nedeniyle 14.02.1992 tarihinde Selanik'te, 10.12.1992 tarihinde Atina'da gösteri yürüyüşleri gerçekleşmiş ve son olarak Prespa Anlaşmasıyla benzer mitingler 2018 yılında da yine Selanik ve Atina'da devam etmiştir.

${ }^{91} \Lambda$ iókos, a.g.e., s. 674-676.

${ }^{92} \Lambda$ ıókos, a.g.e., s. $661,676$.

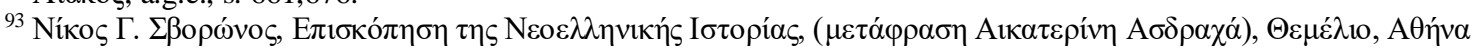
1999.
} 
Svoronos'un kitabı tıpkı kendisi gibi yasaklılar listesindedir. Svoronos, yazdığı bu kitapla aslında Yunanistan'da modern tarih ekolünü de başlatmış olur. ${ }^{94}$ Daha sonra Svoronos'un yarattığ bu yeni tarih ekolünü Spyros Asdrahas, Tarih Araştırmaları ve Tarih Eğitimi. Gerçekler ve Beklentiler $^{95}$, Filippos İliou, Yirminci Yüzyll Siyaseti ve Tarihin Mozaik Taşları ${ }^{96}$ ve Vasilis Panagiotopoulos, Çağdaş Helenizm Tarihi 1770-200097 adlı çalışmalarılla devam ettirmiştir.

Bugün Yunanistan'da yenilikçi tarihyazımını savunan, alışılmışa gelmişin veya malumun ilamı dışında, farklı sesler de çıkartabilen Alkis Angelou, Tasos Kostopoulos, Maria Repousi, Haris Athanasiadis, Christina Koulouri, Lena Divani, Dimitris Christopoulos gibi tarihçiler ortaya koydukları eserleriyle etnosentrik eğilimin dışında daha çok global bir tarih alanı yaratmıştır. Bu noktada Yunan tarihçiliği de değişen ve gelişen siyasetin gölgesinde hala kendi özgür alanını oluşturma çabasında birçok yeni eseri tarih literatürüne sokabilmiştir. Ancak ulusdevlet modelini devam ettiren toplumların sınır ihlallerine karşı savunmacı ve korumacı tutumu günümüzde de Yunan tarihçiliğinin aşamadığı meselelerin başında gelmektedir. Eric Hobsbawm'ın ifadesiyle tarih, milliyetçi, etnik ve fundamentalist ideolojilerin hammaddesidir ve yeni ulusların imal edilmesinde işlevsel malzeme olarak kullanılmıştır. ${ }^{98}$ Dolayısıyla ulus tarihleri söz konusu olduğunda tarih inşasına yeni ve hatta farklı renkte bir tuğla eklemek Yunanlar gibi muhafazakarlık zırhına bürünen toplumlar için kolay aşılabilecek bir duvar değildir. Bugün Yunan tarihçiliğinin kaotik durumu tam da bu gelenekçi ve yenilikçi anlayışın arasında devam eden bir meydan savaşı gibi hala sona erdirilebilmiş değildir.

\section{Sonuç}

Tarihin göreceliğinin en güzel kanıtı aynı olay üzerindeki yorumların değişik olmasıdır. Bu yüzden her tarihi olay, madalyonun öteki yüzü gibi farklı bir cepheye de sahiptir. Türkiye ve Yunanistan'da bu görecelik tarihin birçok safhasında kendisini net gösteren örneklerle doludur. Tıpkı Fransız İhtilali'nın bazı tarihçilerin gözünde insanlığın ilerlemesinin köşe başlarından biri, bazılarının gözünde ise bir yıkım ve isyan dönemi görülmesi gibi Yunan Tarihindeki çoğu terminoloji de birbirlerine zit anlamlarla doludur. Örneğin Yunan Tarihinde 1821 Yunan Devrimi, Türk Tarihinde 1821 Mora İsyanı biçiminde karşılık bulur. Devrim ve İsyan gibi iki uç algı bugün Türk-Yunan tarihçiliğinin terminolojiyi kullanma noktasında belki en zor meselesidir. Ya da Türk Tarihinde Kıbrıs Barış Harekatı, Yunan Tarihinde Kıbrıs İşgali olarak adlandırılır. Bu iki faklı terminoloji ortak tarihyazımının her iki ülkede neden olamayacağının açık kanıtı niteliğindedir.

Her iki ülke arasında var olan bu düalist tutum sadece tarihin “iki farklı yüzü” gibi klişe bir ifadenin çok daha ötesinde siyasetin gölgesinde var olma çabası veren tarih bilimiyle de açıklanmalıdır. Zira Carr'ın da ifade ettiği üzere nesnel olamayan tarih inançlardan, düşünce yapısından soyut düşünülemez. Tarih yazarı, seçtiği konunun yorumunu ne kendi dünya görüşünden, ne iktidar tahayyülünden, ne de iktidarla kendisi arasındaki ilişkiden bağımsız yapamaz. Bu nedenle tarih ve siyasetin arasındaki sarsılmaz köprü, tarihyazımında da kendisine hakimiyet alanı yaratabilmiştir. Bu makalede de incelenen tüm dönemlerin ve siyasi gelişmelerin Yunan tarihçiliğinde tartışılmaz yeri olduğu açıktır. Akademik tezler de dahil birçok tarih kitabı

\footnotetext{
${ }^{94} \Lambda$ iókos, a.g.e., s. 662.

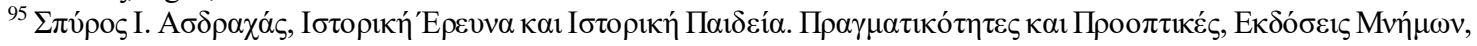
A $\theta \dot{v} v \alpha 1982$.

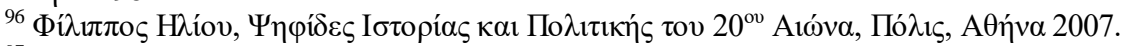

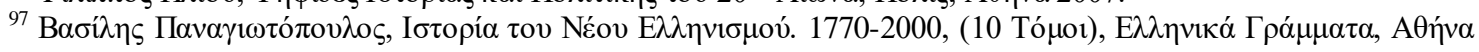
2004.

${ }^{98}$ Erdem Sönmez, Annales Okulu ve Türkiye'de Tarihyazımı. Annales Okulu'nun Türkiye'deki Tarihyazımına Etkisi: Başlangıçtan 1980'e, Tan Kitabevi yay., Ankara 2010, s. 30.
} 
ve tarih dergileri konularını siyasetin gölgesinde gelişen tarihi meselelerden almıştır. Yunan tarihçiliğinin gündemini belirlemek aslında basit birkaç sorunun cevaplanması da demektir. İlki güncel siyaset sorunlarının ne olduğu, ikincisi siyasetin gündemine etki eden geçmişin hangi durumlarda yeniden masaya yatırıldığıdır. Bugün Yunanistan ve diğer ülkelerin tarih meselelerinin temelinde işte bu iki sorunun cevapları yatmaktadır. Kanaatimce ülkelerin tarih gündemleri onların içte ve dışta yaşadığı politik dönüşümlerden bağımsız değerlendirilemez. Çünkü Mark Mazower'ın da ifade ettiği üzere tarih aynadır ve her toplum bu aynaya kendi yöntemiyle bakar.

\section{Kaynakça}

\section{Araştırma Eserleri}

ARISOY, İbrahim Alper \& ÖZDAĞOĞLU, Aşkın \& ÖZDAĞOĞLU, Güzin \& DAMAR, Muhammet, "Yunanistan'da Osmanlı Tarihi Literatürü Üzerine Bir Değerlendirme", Ankara Anadolu ve Rumeli Araştırmaları, Cilt: 1, Sayı: 1, Yaz 2020, s. 5-55.

ARMAOĞLU, Fahir, 20. Yüzyıl Siyasi Tarihi (1914-1995), Timaş Yayınları, İstanbul 2014.

BALTA, Evangelia, "Yunan Tarihçiliğinde Türkçe Arşiv Materyalleri”, Çeviren: Cemile Erdek, Türkiye Araştırmaları Literatür Dergisi, Cilt: 8, Sayı: 15, 2010, s. 793-832.

BERATLI, Nazım, “Bilim mi - Sanat mı - Propaganda mı? Tarih Nedir?”, Kıbrıs Yazıları, Sa: 3, (Yaz/Güz-2006), s. 3-20.

BERKTAY, Halil, "Tarih ve Siyaset", http://serbestiyet.com/yazarlar/halil-berktay/tarih-vesiyaset-849090 Erişim Tarihi: 15.01.2020.

CARR, Edward H., Tarih Nedir?, İletişim Yayınları, İstanbul 2013.

CLOGG, Richard, Modern Yunanistan Tarihi, İletişim Yayınları, İstanbul 1997.

İNALCIK, Halil, “Tarih ve Politika”,Prof. Dr. Halil İnalcık'ın 29 Mart 2006 tarihinde Ankara Üniversitesi Rektörlüğü 100. Yıl Salonu'nda sunduğu Tarih ve Politika konulu konferans metni,ss. 7-11.

JENKINS, Keith, Tarihi Yeniden Düşünmek, Dost Yayınevi, Ankara 1997.

KAYA, Ayhan \& AYDIN DÜZGIT, Senem \& GÜRSOY, Yaprak \& ONURSAL BEŞGÜL, Özge (der.), Avrupa Birliği'ne Giriş: Tarih, Kurumlar ve Politikalar, İstanbul Bilgi Üniversitesi yay., İstanbul 2011.

ÖZLEM, Doğan, Tarih Felsefesi, Notos Kitap, İstanbul 2012.

ÖZSÜER, Esra, “Tarihin resmi ideoloji Tarafindan Tahrifatına Bir Örnek: Yunanistan”, Turkish History Education Journal, Fall 2018, 7(2), s. 466-508.

RANKE, Leopold Von, The Secret of World History: Selected Writings on the Art and Science of History, Edited by Roger Wines, Fordham University Press, New York 1981.

SÖNMEZ, Erdem, Annales Okulu ve Türkiye'de Tarihyazımı. Annales Okulu'nun Türkiye'deki Tarihyazımına Etkisi: Başlangıçtan 1980'e, Tan Kitabevi yay., Ankara 2010.

TOSH, John, Tarihin Peşinde, Çeviren: Özden Arıkan, Tarih Vakfı Yurt yay., İstanbul 1997.

BАКА ОПОҮ $\Lambda \mathrm{O} \Sigma$, А

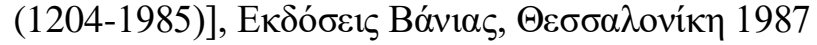




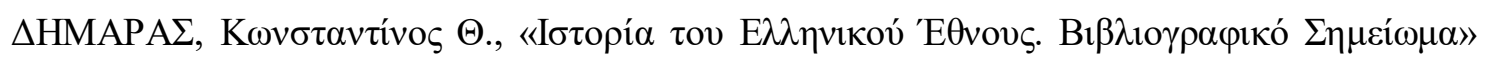

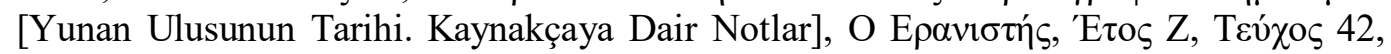
A0ฑ́va 1969, s. 193-202.

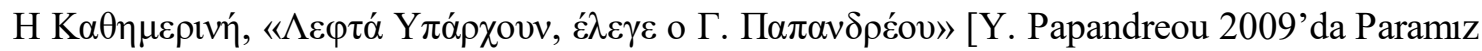
var demişti], 16.09.2014, https://www.kathimerini.gr/783966/article/epikairothta/politikh/lefta-yparxoyn-elege-og-papandreoy-to-2009. [Erişim Tarihi: 12.08.2020]

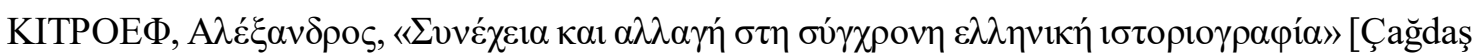

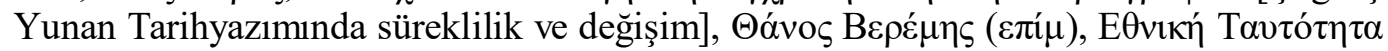

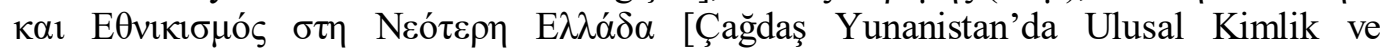

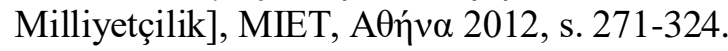

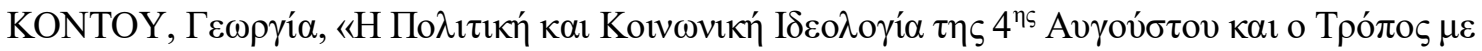

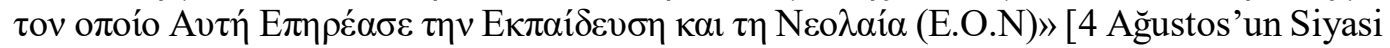

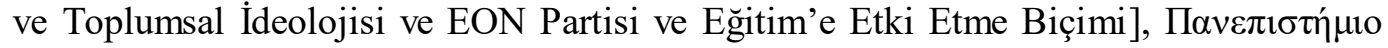

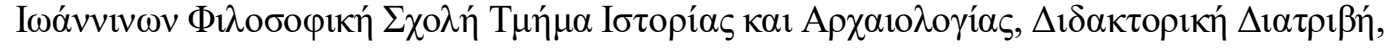
I $\omega \alpha ́ v v i v \alpha 2013$.

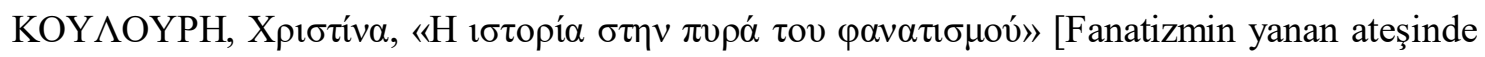

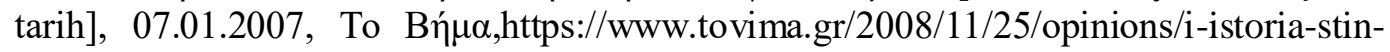
pyra-toy-fanatismoy/

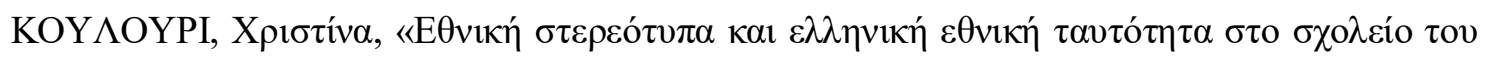

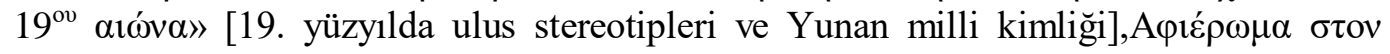

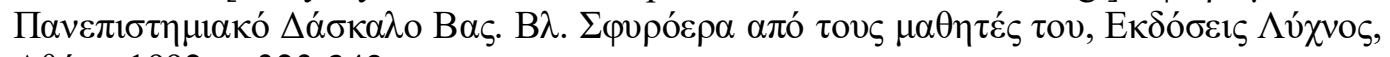
Aө̛́va 1992, s. 323-342.

Volume 12

Issue 6

December

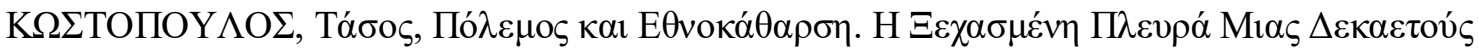

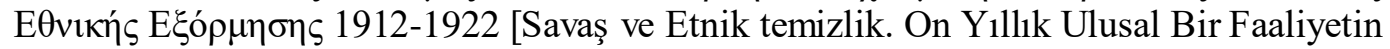

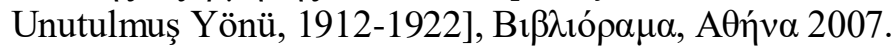

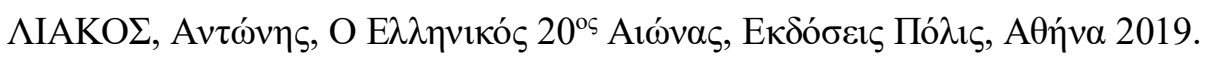

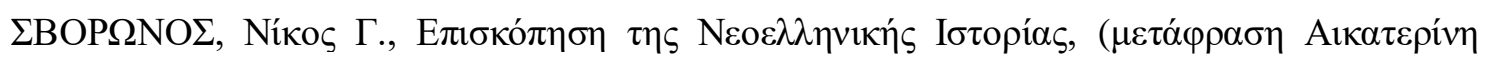

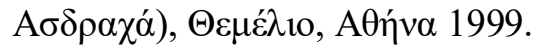

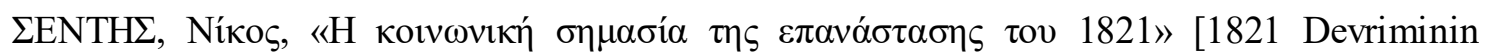
toplumsal önemi], https://marxismos.com/koinwniki-simasia-epanastasi-1821/ [Erişim tarihi: 18.05 .2020$]$

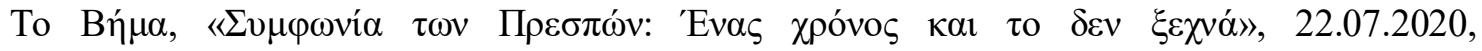
https://www.tovima.gr/2019/06/17/politics/symfonia-ton-prespon-enas-xronos-kai-totwitter-den-ksexna/ [Erişim Tarihi: 22.07.2020]

\section{2. İncelenen Kitap ve Makaleler}

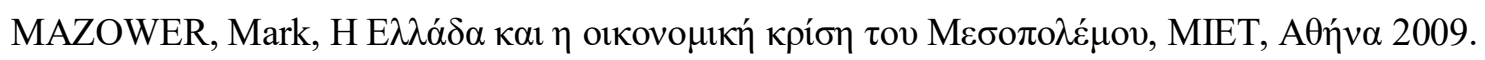

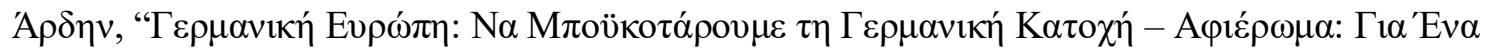

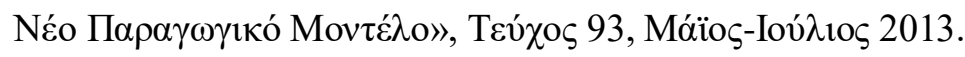

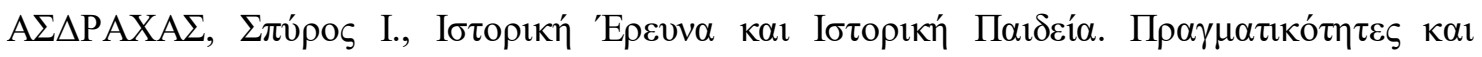

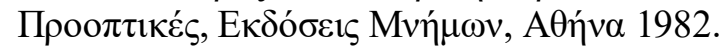


ВАКА $\Lambda$ ОПОҮ $\Lambda \mathrm{O} \Sigma$, А

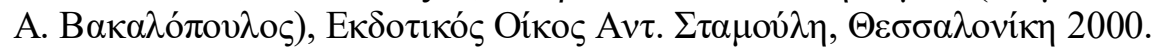

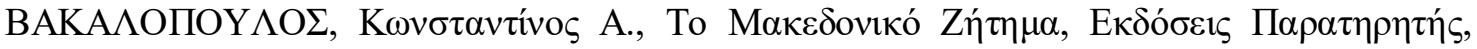
A $\theta \dot{v} v \alpha 1993$.

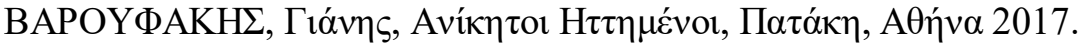

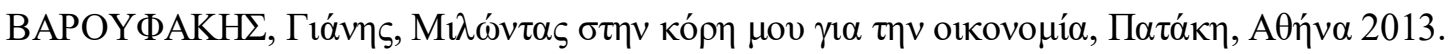

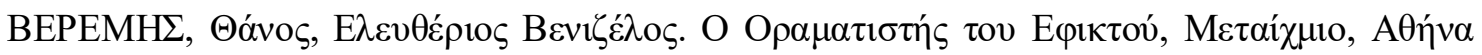
2017.

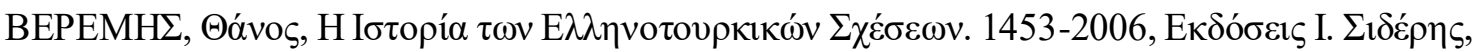
A $\theta \dot{v} v \alpha 2007$.

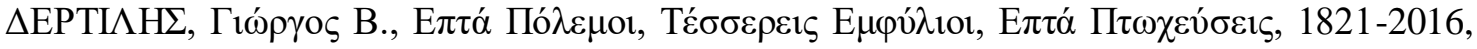

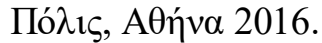

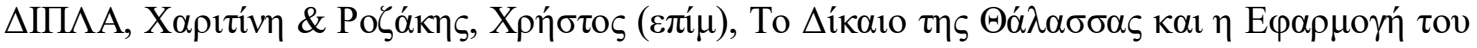

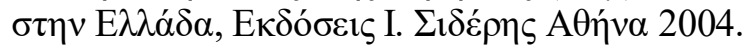

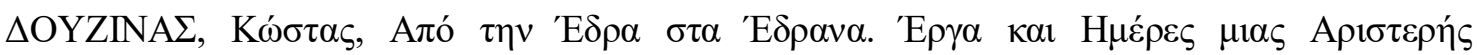

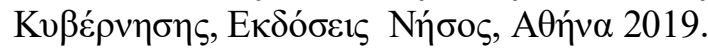

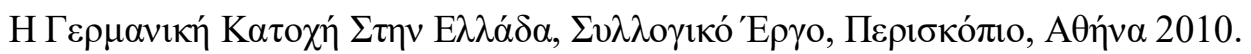

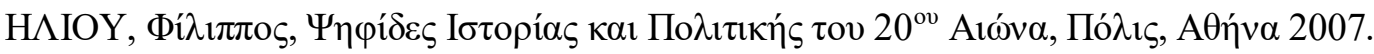

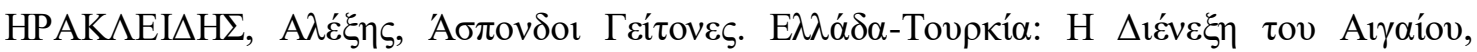

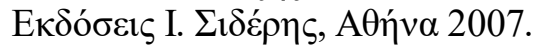

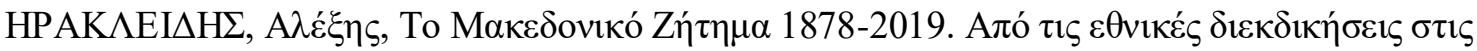

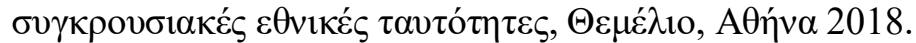

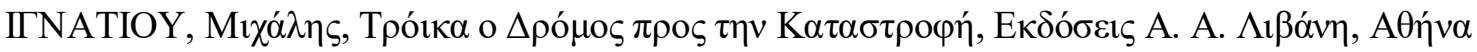
2015.

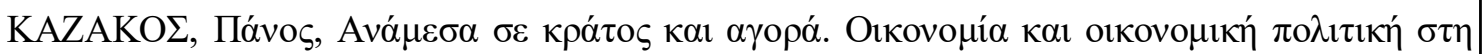

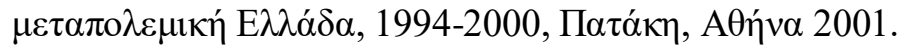

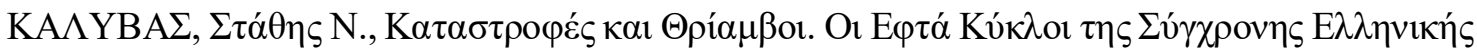

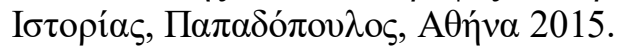

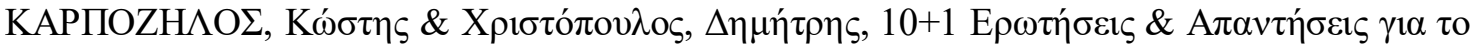

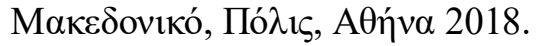

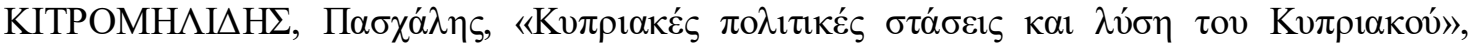

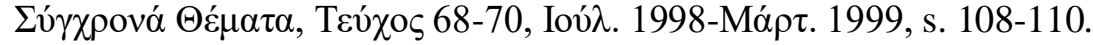

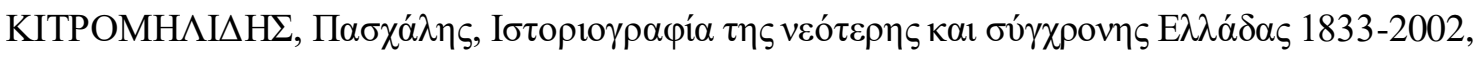
KNE-EIE, A $\theta \dot{v} v \alpha 2004$.

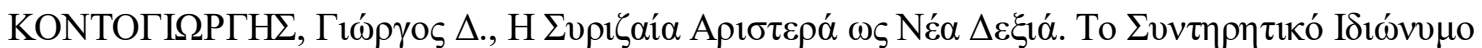

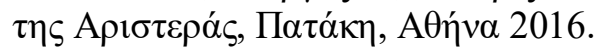

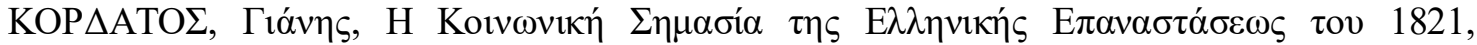

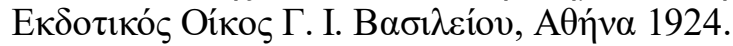




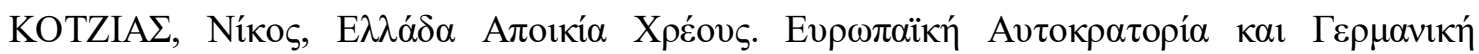

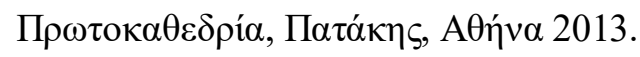

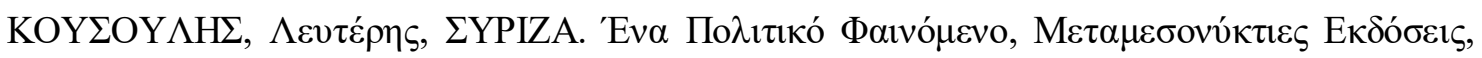
A $\theta \dot{v} v \alpha 2019$.

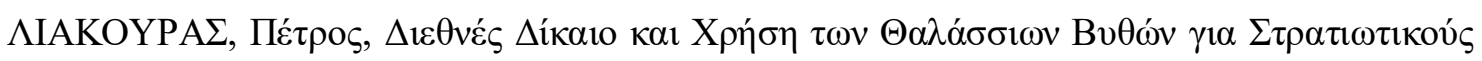

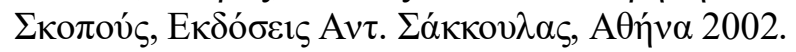

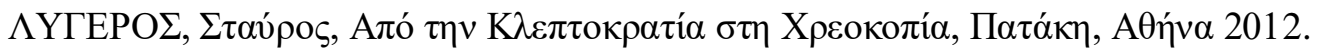

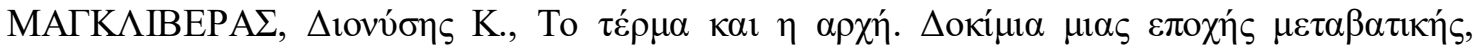

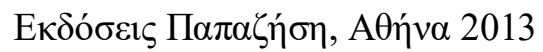

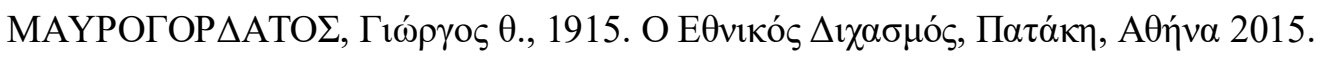

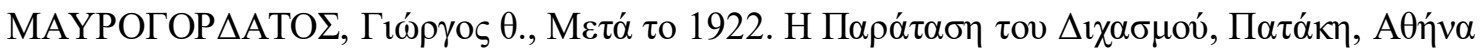
2018.

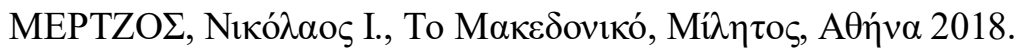

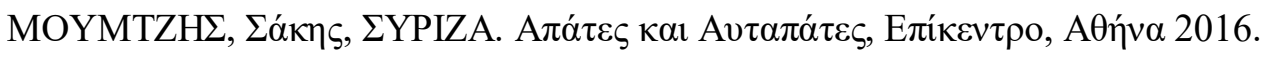

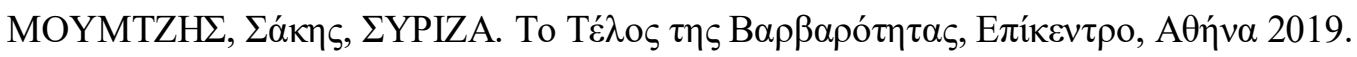

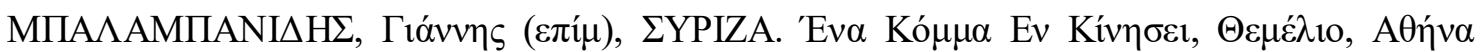
2019.

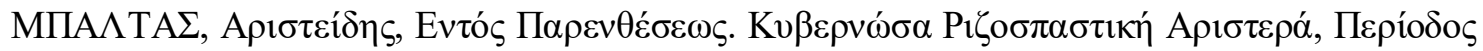

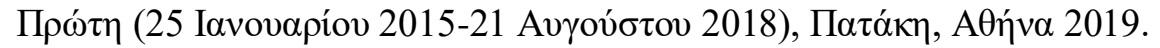

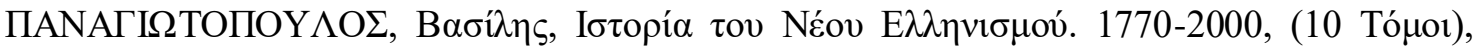

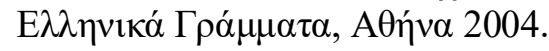

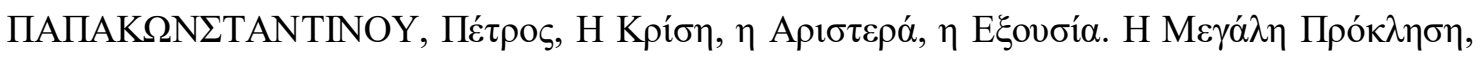

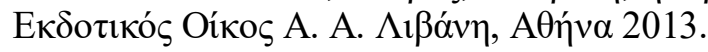

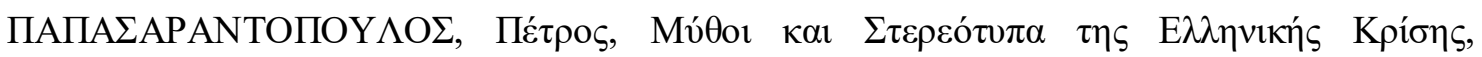

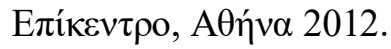

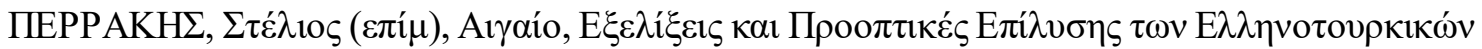

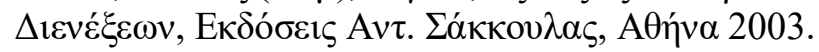

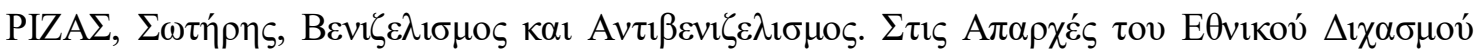

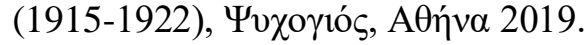

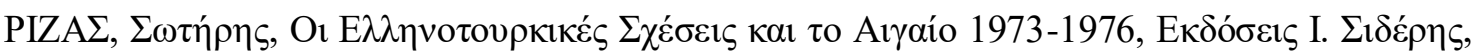
A 0 ท́va 2006.

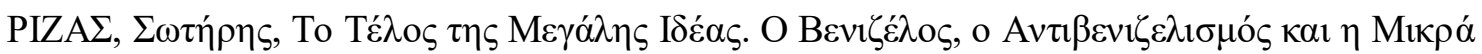

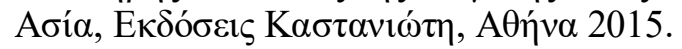

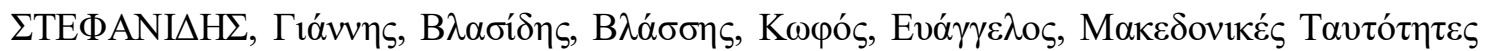

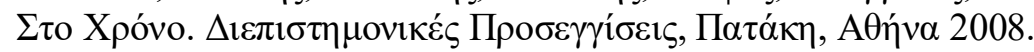

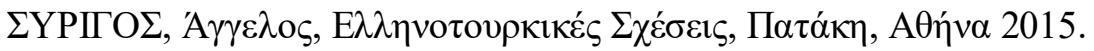

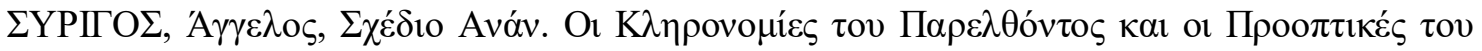

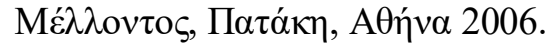




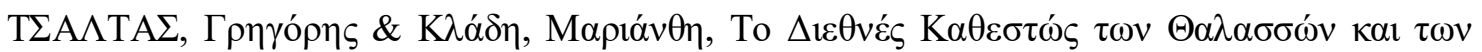

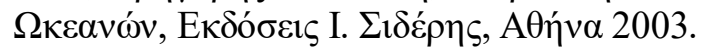

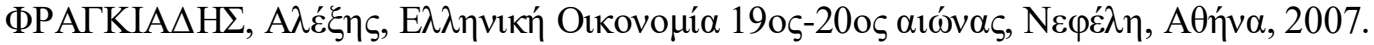

\section{3. İnternet Sayfası}

http://www.ekt.gr [Erişim tarihi: 19.07.2020]

https://www.didaktorika.gr/eadd/[Erişim tarihi: 19.07.2020] 